Article

\title{
Effect of Salt Bath Nitrocarburizing and Post-Oxidation on Static and Fatigue Behaviours of a Construction Steel
}

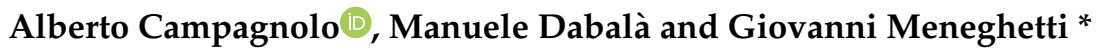 \\ Department of Industrial Engineering, University of Padova, Via Venezia, 1-35131 Padova, Italy; \\ alberto.campagnolo@unipd.it (A.C.); manuele.dabala@unipd.it (M.D.) \\ * Correspondence: giovanni.meneghetti@unipd.it; Tel.: +39-049-8276751
}

Received: 1 November 2019; Accepted: 2 December 2019; Published: 4 December 2019

check for updates

\begin{abstract}
Several surface modification technologies are typically applied to improve the mechanical properties of the material surface of structural components subjected to severe conditions of load, wear and chemical erosion of the surface. The nitrocarburizing and post-oxidation heat treatment, also known as quench-polish-quench (QPQ), improves the fatigue, wear and corrosion resistance properties of the material, since it increases the surface hardness and generates surface compressive residual stresses. In the present contribution, the effects of the salt bath nitrocarburizing and post-oxidation heat treatment on the static and fatigue behaviours of $39 \mathrm{NiCrMo} 3$ construction steel have been investigated by experimentally testing plain as well as notched specimens. For comparison purposes, $39 \mathrm{NiCrMo} 3$ construction steel, both untreated and treated, and $\mathrm{X} 5 \mathrm{CrNiCuNb} 16-4$ stainless steel have been tested. First, the microstructure of the untreated and treated steel has been identified by metallographic analysis; micro-hardness measurements have been collected and residual stresses profiles have been obtained by using the $X$-ray diffraction technique. Then, experimental static and fatigue tests have been performed. Finally, the fracture surfaces have been analysed to locate fatigue crack nucleation sites.
\end{abstract}

Keywords: nitrocarburizing; steel; strength; fatigue; notch

\section{Introduction}

In the last decades, several surface treatments and coatings [1-4] have been developed for mechanical components facing severe in-service conditions in terms of load, wear, and chemical corrosion, such as gears, crankshafts, extrusion and forging dies, valves and springs. Surface treatments can be classified in mechanical (e.g., shot peening and deep rolling), thermal (e.g., quenching and tempering) and diffusion (e.g., carburizing, nitriding, carbonitriding and nitrocarburizing), while coatings may involve metalling or non-metallic protective paints. Among the available surface treatments, the nitrocarburizing is widely applied to components made of ferrous alloys to enhance wear as well as corrosion resistance and fatigue strength. Essentially, this treatment increases the surface hardness and generates a compressive residual stress state on the surface of the component. It can be applied by means of three different media: gas, liquid and plasma [5-10]. The liquid nitrocarburizing in salt bath has been widely employed in industry since the 1940s; however, this method had a major issue related to toxicity of the cyanide-cyanate salt, which was solved in 1970 [11] by adopting a nontoxic cyanate-bearing bath. Later on, in the 1980s, an advanced salt bath heat treatment, given by the combination of nitrocarburizing and post-oxidation, known also as quench-polish-quench (QPQ) treatment, has been proposed and, then, widely employed in industrial applications, since it was demonstrated that the additional process of post-oxidation after nitrocarburizing further enhances the mechanical properties of the treated materials [12-18]. 
The improvement of fatigue strength after the nitrocarburizing treatment is mainly due to the appearance of surface compressive residual stresses [6,10]. Strictly speaking, dealing with conventional materials, fatigue cracks mostly initiated at the surface of the structural components due to slip deformation of crystals or surface defects. On the other hand, concerning surface hardened materials, cracks can still initiate and propagate at the surface; however, if the increased hardness and the compressive surface residual stress state are sufficient to prevent surface crack initiation and subsequent propagation, then the crack initiation location can be shifted from the outer surface into the core of the component at internal defects. Therefore, the fatigue failure phenomenon can highlight a competition between surface and internal cracks, one of which eventually being dominant for the final failure [19-21]. As a result, it is well known in the literature that the fatigue curves of high-strength or surface hardened steels can be modelled as 'stepwise curves', resulting from the superposition of two curves [22-24]: one relevant to surface-initiated failure, and the other one relevant to internal-initiated failure. In some cases, the 'stepwise fatigue curves' show a marked transition between the two curves, which represents the so-called fatigue limit relevant to the surface-initiated failure. It is worth noting that the internal-induced failure typically occurs in the very-high-cycle fatigue regime (VHCF) $[23,25]$, i.e., for fatigue lives in the range between $10^{7}$ and $10^{9}$ cycles. However, the surface hardening can shift the transition between surface-induced and internal-induced fatigue failure in the medium-cycle fatigue regime, i.e., between $10^{4}$ and $10^{5}$ cycles $[10,24]$.

In previous contributions, several authors have analysed the effect of nitrocarburizing on the fatigue limit of the plain material [26-31], while only few contributions [10,24] have been devoted to investigating the effect of nitrocarburizing on the medium-high cycle fatigue regime, considering both plain and notched specimens. Moreover, the effects of the combination of salt bath nitrocarburization and post-oxidation, i.e., QPQ treatment, have been mainly analysed from the point of view of microstructure, hardness, wear and corrosion resistance [14-18,32], while the effects of QPQ treatment on the fatigue behaviour have been investigated in detail only for some steel categories, such as carbon steels [33-35], alloyed steels [36,37], tool steel [38]; and also for ductile cast iron [39].

In this context, the effects of the salt bath nitrocarburizing and post-oxidation heat treatment on the static and fatigue behaviours of $39 \mathrm{NiCrMo} 3$ construction steel have been investigated in present contribution. The $39 \mathrm{NiCrMo} 3$ steel is widely adopted in highly stressed components for aircraft, automotive and general engineering applications, such as forged propeller shafts, connecting rods, gear shafts, crankshafts and landing gear components. However, the $39 \mathrm{NiCrMo} 3$ steel in the untreated condition is not suitable for structural applications requiring high corrosion resistance, therefore in these cases a proper surface treatment is required. To overcome this issue, a possible solution is the adoption of the QPQ treatment. For comparison purposes, also the $\mathrm{X} 5 \mathrm{CrNiCuNb} 16-4$ stainless steel has been considered in the investigation, since it has both static and fatigue performances similar to those of $39 \mathrm{NiCrMo} 3$ steel, but it has also good corrosion resistance, without requiring for a surface treatment. Afterwards, the aims of the present contribution are:

(1) To analyse the microstructure of the untreated and treated $39 \mathrm{NiCrMo} 3$ steel by metallographic and SEM analyses and to measure the micro-hardness and surface residual stress profiles.

(2) To carry out experimental static and fatigue tests on plain as well as notched specimens, made of $39 \mathrm{NiCrMo} 3$ construction steel, both untreated and treated, and, for comparison purposes, also on specimens made of $\mathrm{X} 5 \mathrm{CrNiCuNb} 16-4$ stainless steel.

(3) To analyse the fracture surfaces of the tested specimens to identify the fatigue crack initiation locations.

\section{Materials and Methods}

\subsection{Materials and Specimen Geometries}

The tested materials are a construction steel, i.e., $39 \mathrm{NiCrMo3}$, and a stainless steel, i.e., $\mathrm{X} 5 \mathrm{CrNiCuNb}$ 16-4, whose chemical compositions are reported in Table 1 . The specimen geometries, which include 
plain as well as notched specimens with notch opening angle of $60^{\circ}$ and notch tip radius of $1.5 \mathrm{~mm}$, are reported in Figure 1a-c, respectively.

Table 1. Chemical composition (wt.\%) of the considered materials (Fe balance).

\begin{tabular}{ccccccccccccccc}
\hline Material & $\mathbf{C}$ & $\mathbf{S i}$ & $\mathbf{M n}$ & $\mathbf{P}$ & $\mathbf{S}$ & $\mathbf{C r}$ & $\mathbf{M o}$ & $\mathbf{N i}$ & $\mathbf{C u}$ & $\mathbf{N b}$ & $\mathbf{T i}$ & Al & Sn & $\mathbf{C o}$ \\
\hline 39NiCrMo3 & 0.4 & 0.27 & 0.71 & 0.016 & 0.02 & 0.83 & 0.19 & 0.78 & 0.23 & 0.002 & 0.13 & 0.02 & 0.012 & - \\
X5CrNiCuNb 16-4 & 0.14 & 0.27 & 0.86 & 0.022 & 0.027 & 15.57 & 0.12 & 4.52 & 3.26 & 0.24 & - & - & - & 0.020 \\
\hline
\end{tabular}
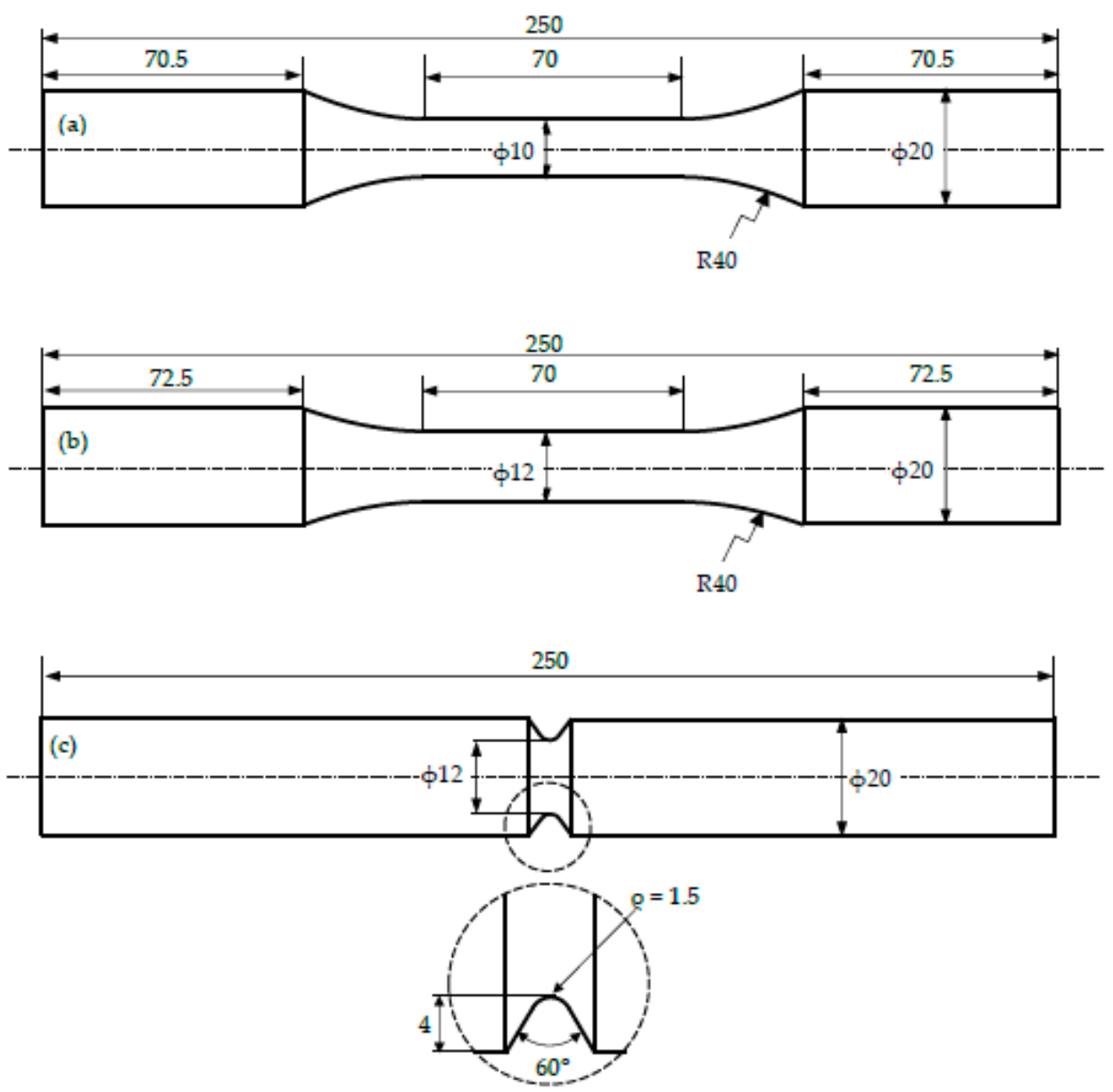

Figure 1. Geometry of (a) and (b) plain specimens and (c) circumferentially notched specimens (dimensions are in $\mathrm{mm}$ ).

\subsection{Salt Bath Nitrocarburization and Post-Oxidation $(Q P Q)$ Heat Treatment}

The $39 \mathrm{NiCrMo} 3$ construction steel has been considered both in the untreated and in the treated conditions. The applied heat treating process, also known as quench-polish-quench (QPQ), mainly consists of the following steps (Figure 2): (i) pre-heating, (ii) nitrocarburizing, (iii) oxidizing, (iv) cooling, (v) polishing and, finally, (vi) post-oxidising. The specimens were preheated at about $350{ }^{\circ} \mathrm{C}$ in air and then nitrocarburized in salt bath at about $580^{\circ} \mathrm{C}$. After that the samples have been oxidized and cooled in water; then they were polished and, finally, exposed to further post-oxidation in salt bath at about $350{ }^{\circ} \mathrm{C}$ and then cooled in water to room temperature. 


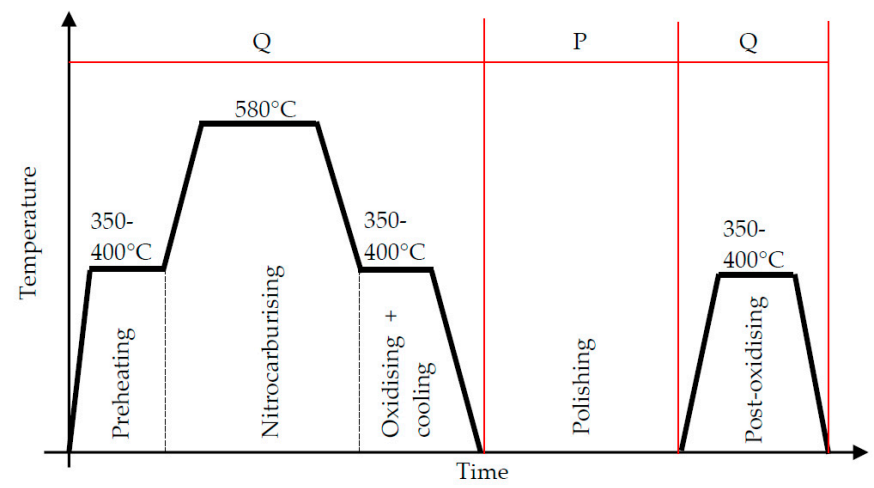

Figure 2. Salt bath nitrocarburizing and post-oxidation heat-treatment, also known as quench-polish-quench treatment (QPQ), performed on 39NiCrMo3 construction steel.

\subsection{Microstructure and Microhardness}

The microstructural analysis has been performed on the polished surface sections of plain as well as notched specimens made of $39 \mathrm{NiCrMo} 3$ construction steel in both untreated and treated conditions. The specimens have been etched by a solution composed by $3 \%$ of perchloric acid, $10 \%$ of butoxyethanol, $73 \%$ of ethanol and $9 \%$ of water. Leica DRME optical microscope (Leica, Wetzlar, Germany) and Cambridge 440 Scanning Electron Microscope (SEM) (Leica, Wetzlar, Germany) equipped with EDS EDAX microbeam have been employed.

The microhardness Vickers measurements have been performed by a Leitz Durimet microdurimeter (Leitz, Wetzlar, Germany) by applying a $0.5 \mathrm{~N}$ load for $15 \mathrm{~s}$.

\subsection{Surface Residual Stresses}

The surface residual stresses have been measured on plain as well as notched specimens made of $39 \mathrm{NiCrMo} 3$ construction steel in both untreated and treated conditions by the X-ray diffraction method, therefore all in all four specimens have been measured. Figure 3 reports the measurement point for the case of plain specimens, at which the axial $\sigma_{\mathrm{xx}}$ and hoop $\sigma_{\mathrm{zz}}$ residual stresses were measured. First, the oxide black layer on the surface of treated specimen has been removed by electrochemical polishing. The $\sin ^{2} \psi$-method has been applied to measurements performed by the X-ray diffractometer (XRD) GNR Spider X (GNR, Novara, Italy), which adopts a $\mathrm{Cr} \mathrm{K} \alpha$ wavelength with an acquisition time of 500 s per $\psi$ angle on $7 \psi$-angles in the range $-45^{\circ}<\psi<45^{\circ}$. According to this technique, a strain is measured from the deformation of the crystal lattice. After that, the residual stress related to this strain is derived assuming a linear elastic material behaviour.

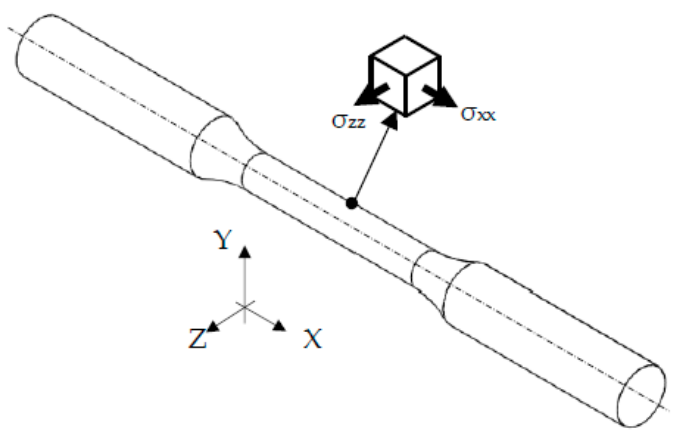

Figure 3. Residual stress components and location for residual stress measurement. 


\subsection{Static and Fatigue Experiments}

Static as well as fatigue experimental tests have been performed on specimens made of $39 \mathrm{NiCrMo} 3$ construction steel, both in the untreated and in the treated conditions, and, for comparison purposes, also on specimens made of $\mathrm{X} 5 \mathrm{CrNiCuNb} 16-4$ stainless steel. A MFL axial servo-hydraulic testing machine (Mohr \& Federhaff \& Losenhausen, MFL, Germany), having a load capacity of $250 \mathrm{kN}$ and being equipped with a MTS TestStar IIm controller (MTS, Eden Prairie, MN, USA), has been adopted.

Tensile static tests have been executed on plain specimens (Figure 1a) by applying a displacement rate equal to $2 \mathrm{~mm} / \mathrm{min}$ under displacement control. The uniaxial MTS extensometer (MTS, Eden Prairie, MN, USA) having gauge length of $25 \mathrm{~mm}$ has been adopted. Three samples of each material have been tested. The MTS controller acquired the applied load from the load cell of the testing machine and the strain from the extensometer during each static test.

Axial fatigue tests have been performed on plain (Figure 1b) as well as notched (Figure 1c) specimens by imposing a sinusoidal load cycle under closed-loop load control, by adopting a nominal load ratio R equal to -1 and a frequency $f$ in the range $10-30 \mathrm{~Hz}$ as a function of the applied load level. All fatigue tests have been interrupted at specimen complete separation, while run out condition has been defined at $5 \times 10^{6}$ cycles. Given the axial load amplitude $F_{a}$ applied to the specimen, the nominal stress amplitude in the net-section has been calculated from the following expression:

$$
\sigma_{\mathrm{a}, \text { net }}=\frac{\mathrm{F}_{\mathrm{a}}}{\mathrm{A}_{\text {net }}}=\frac{\mathrm{F}_{\mathrm{a}}}{\frac{\pi}{4} \cdot \mathrm{d}_{\text {net }}^{2}}
$$

where $d_{\text {net }}$ is the diameter of the specimen net-section, as reported in next Table 5 .

\section{Results}

\subsection{Microstructure}

Dealing with plain and notched specimens made of untreated 39NiCrMo3 steel, the microstructure is typical of a tempered steel: Figure $4 a, c$ and Figure $5 a, c$ show very fine grains and small particles of carbides obtained after heat treatment performed on the quenched steel at a temperature close to $600{ }^{\circ} \mathrm{C}$. The resulting microstructure is composed by tempered martensite with a fine precipitation of carbides (light particles in Figures $4 \mathrm{a}$ and $5 \mathrm{a}$ and also in SEM pictures, i.e., Figure $6 \mathrm{a}, \mathrm{b}$ ). The grain size in the untreated sample, Figure $6 \mathrm{a}$, is between 5 to $8 \mu \mathrm{m}$. The QPQ treatment produced a slight growth of carbide particles and a refinement in the structure of the tempered martensite, Figure $6 \mathrm{~b}$.

Concerning plain and notched specimens made of treated $39 \mathrm{NiCrMo} 3$ steel, Figures $4 \mathrm{~b}$ and $5 \mathrm{~b}$ show that the QPQ treatment does not affect the bulk microstructure, which indicates that the tempering temperature was higher than the maximum temperature of the QPQ treatment. On the other hand, Figures $4 \mathrm{~d}$ and $5 \mathrm{~d}$ show that treated specimens present a light outer layer with a thickness of about $10 \mu \mathrm{m}$ and $15 \mu \mathrm{m}$ (Figure $4 \mathrm{~d}$ ) for plain and notched specimens, respectively, which is constituted by an external porous layer and an internal compact layer. By comparing optical micrographs (Figures $4 \mathrm{~d}$ and $5 \mathrm{~d}$ ) and SEM images (Figure 7a-d), it can be noted that the relative thickness of the porous layer is higher in the notched specimen than in the plain one. The porous layer is composed by iron nitrides and oxides, which contain small amounts of chromium as shown in the EDS analysis of Figure 8. The amount of oxides is slightly higher in the notched specimen than in the plain one (Table 2). The compact layer is composed only by iron nitrides which contain a small amount of chromium. It can be observed from the SEM images (Figure 7e-f) that close to the compact layer there are particles of nitrides at the grain boundaries of the tempered martensite, due to the diffusion of nitrogen during the nitrocarburizing treatment. This diffusion zone is evident also in the optical microscope images (Figures $4 \mathrm{~d}$ and $5 \mathrm{~d}$ ) and its thickness is about $150 \mu \mathrm{m}$ in the plain sample and about $100 \mu \mathrm{m}$ in the notched sample. 


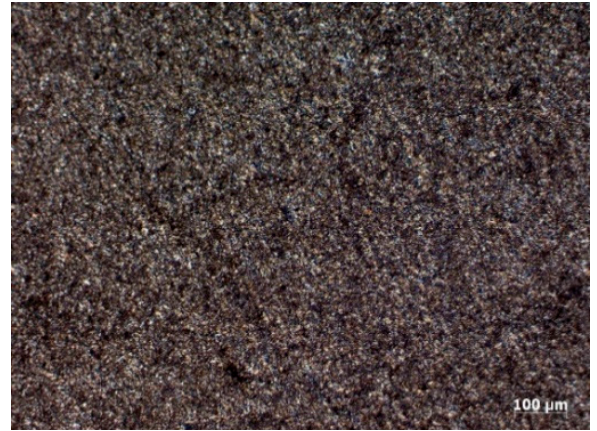

(a)

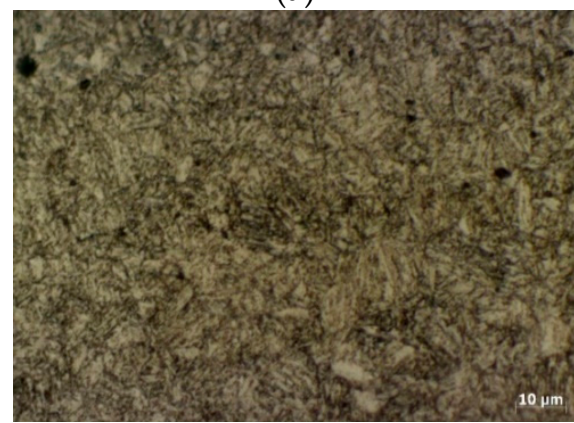

(c)

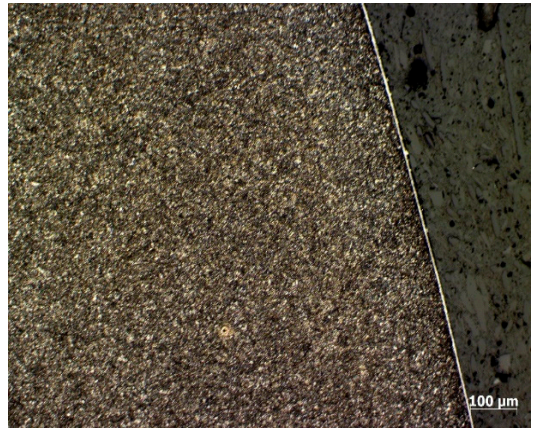

(b)

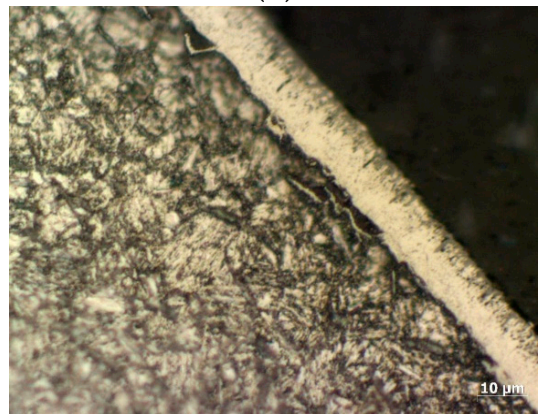

(d)

Figure 4. Micrographic analysis of the cross-section of plain specimens (Figure 1b) made of $(\mathbf{a}, \mathbf{c})$ 39NiCrMo3 and (b,d) 39NiCrMo3 + QPQ steels.

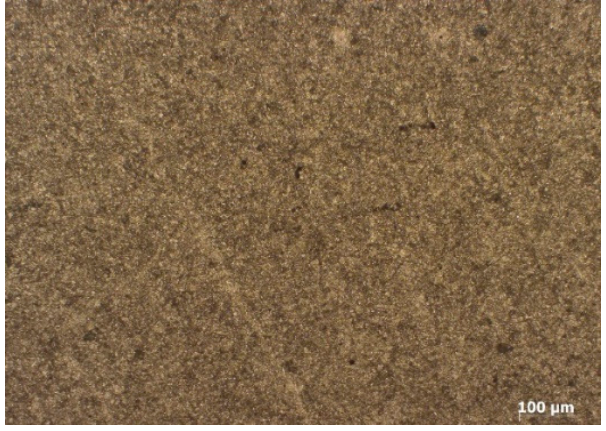

(a)

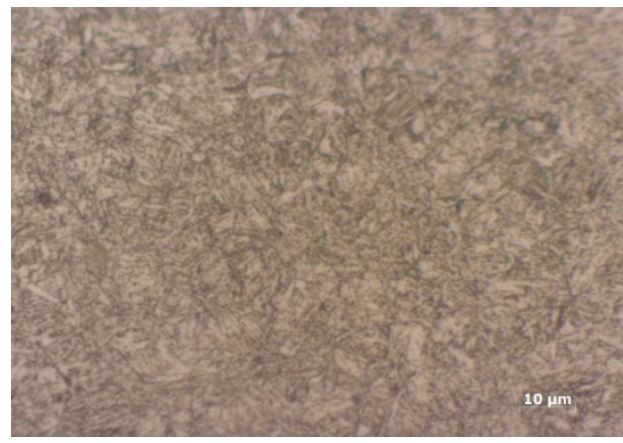

(c)

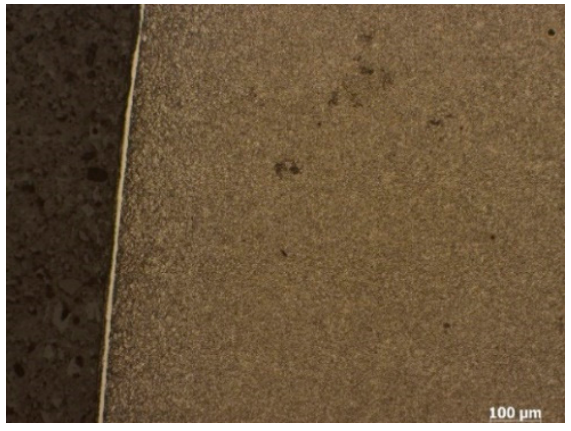

(b)

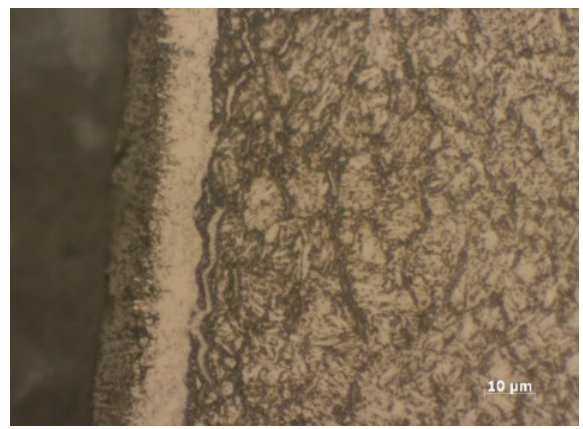

(d)

Figure 5. Micrographic analysis of the cross-section of notched specimens (Figure 1c) made of (a,c) $39 \mathrm{NiCrMo} 3$ and $(\mathbf{b}, \mathbf{d}) 39 \mathrm{NiCrMo} 3+$ QPQ steels. 


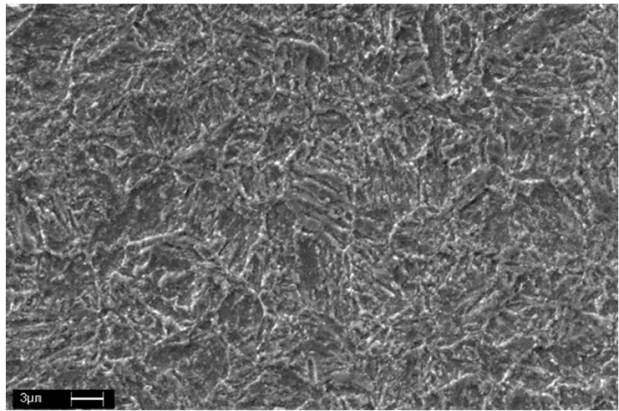

(a)

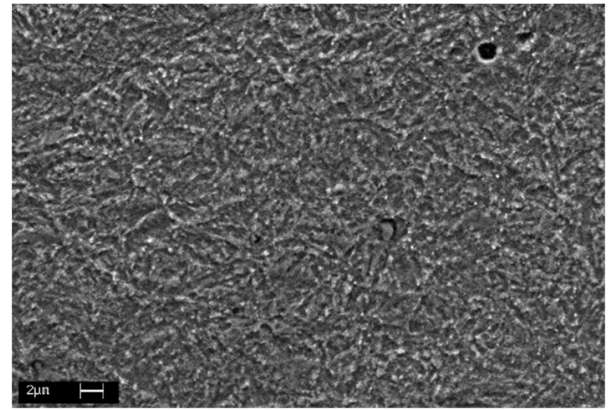

(b)

Figure 6. SEM analysis of the cross-section of plain specimens (Figure 1b) made of (a) $39 \mathrm{NiCrMo} 3$ and (b) $39 \mathrm{NiCrMo} 3+\mathrm{QPQ}$ steels.

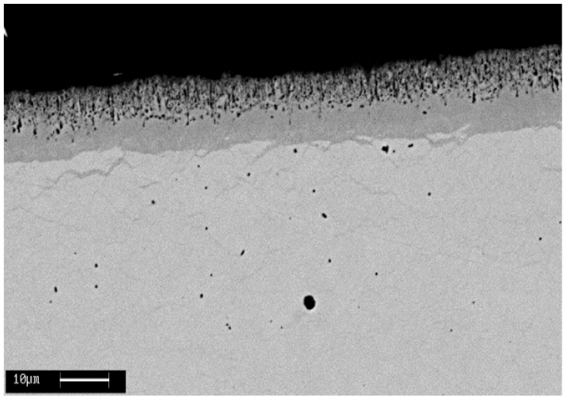

(a)

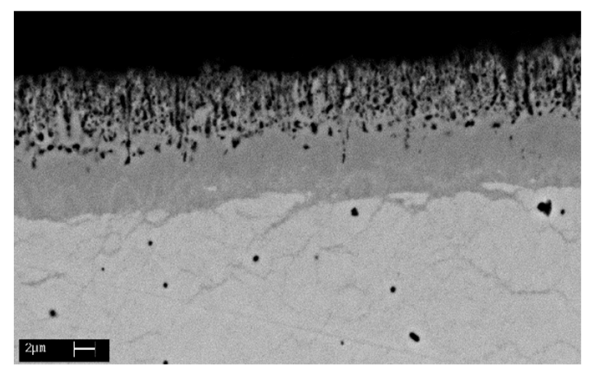

(c)

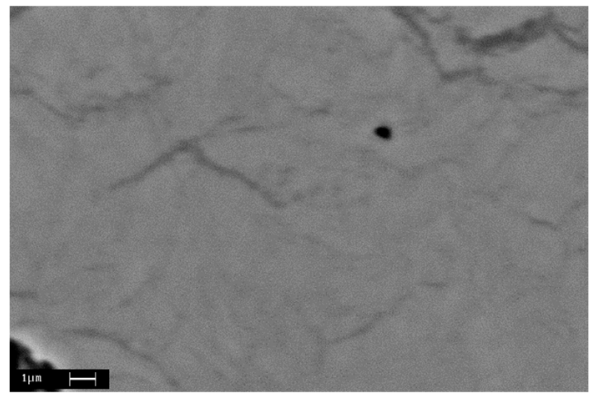

(e)

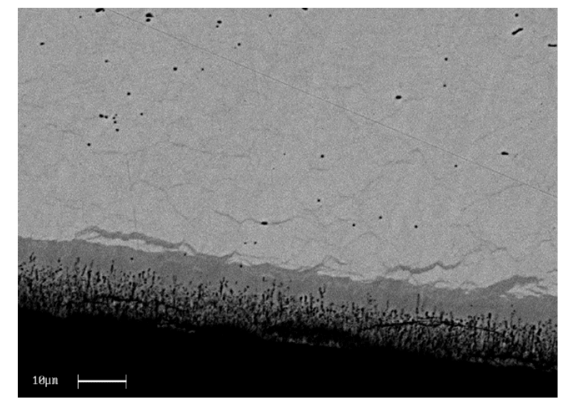

(b)

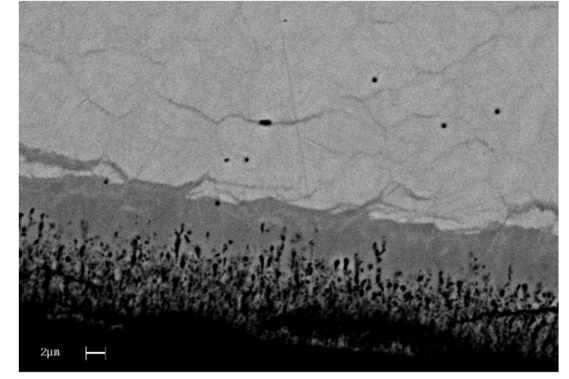

(d)

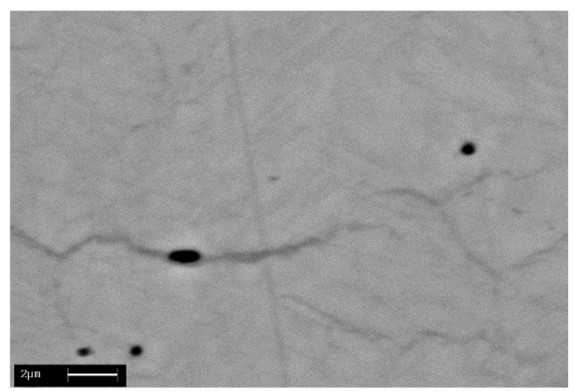

(f)

Figure 7. SEM analysis of the cross-section of $(\mathbf{a}, \mathbf{c}, \mathbf{e})$ plain specimen (Figure $1 \mathbf{b})$ and $(\mathbf{b}, \mathbf{d}, \mathbf{f})$ notched specimen (Figure 1c) made of 39NiCrMo3 + QPQ steel. 


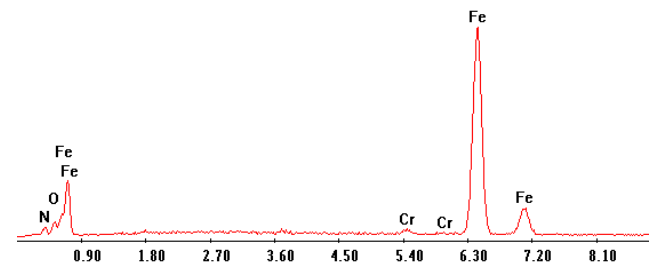

(a) porous outer layer

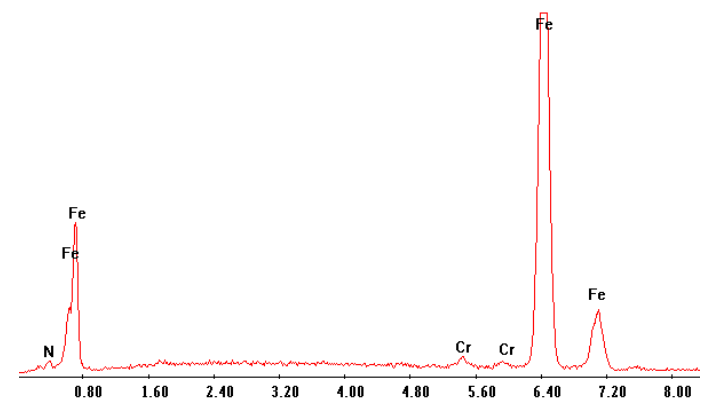

(c) compact layer

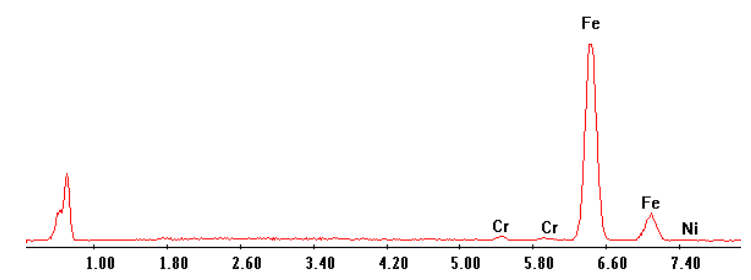

(e) core

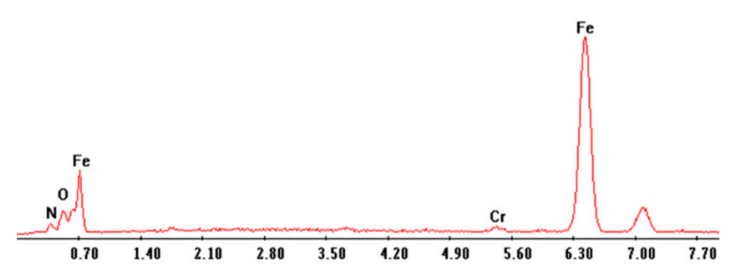

(b) porous outer layer

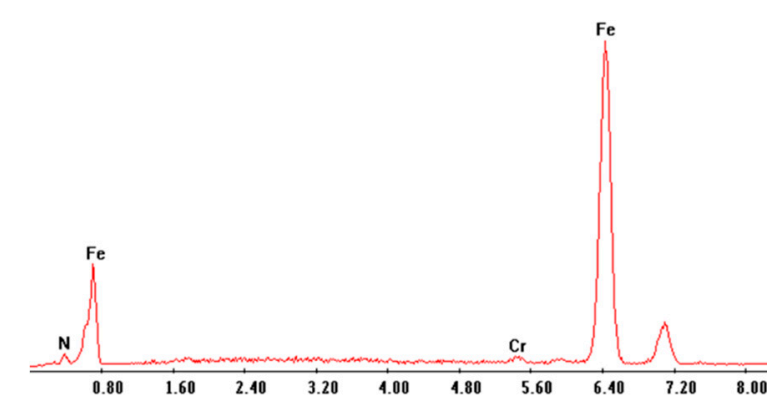

(d) compact layer

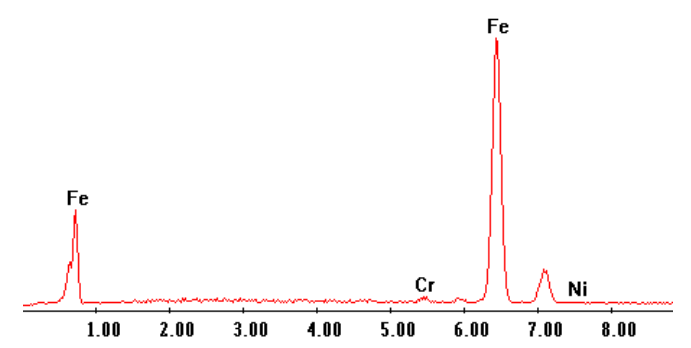

(f) core

Figure 8. EDS patterns of $(\mathbf{a}, \mathbf{b})$ the porous outer layer, $(\mathbf{c}, \mathbf{d})$ compact layer, $(\mathbf{e}, \mathbf{f})$ core at the cross-section of $(\mathbf{a}, \mathbf{c}, \mathbf{e})$ plain specimen (Figure $1 \mathbf{b})$ and $(\mathbf{b}, \mathbf{d}, \mathbf{f})$ notched specimen (Figure 1c) made of $39 \mathrm{NiCrMo} 3+$ QPQ steel. Values are reported in Table 2.

Table 2. EDS semiquantitative analysis (Figure 8) for different layers of the cross-section of plain and notched specimens made of $39 \mathrm{NiCrMo3}+$ QPQ steel.

\begin{tabular}{|c|c|c|c|c|c|c|c|c|}
\hline Material & $\begin{array}{c}\text { Specimen } \\
\text { Geometry }\end{array}$ & Layer & $\begin{array}{c}\mathrm{Fe} \\
(\%)\end{array}$ & $\begin{array}{l}\mathrm{Cr} \\
(\%)\end{array}$ & $\begin{array}{c}\mathrm{Ni} \\
(\%)\end{array}$ & $\begin{array}{c}\mathrm{N} \\
(\%)\end{array}$ & $\begin{array}{c}\mathrm{O} \\
(\%)\end{array}$ & $\begin{array}{c}\mathrm{S} \\
(\%)\end{array}$ \\
\hline \multirow{6}{*}{$\begin{array}{c}\text { 39NiCrMo3 } \\
+ \text { QPQ }\end{array}$} & \multirow{3}{*}{ Plain } & $\begin{array}{c}\text { Porous outer } \\
\text { layer }\end{array}$ & 69.02 & 0.87 & - & 18.40 & 11.71 & - \\
\hline & & $\begin{array}{l}\text { Compact } \\
\text { layer }\end{array}$ & 84.24 & 1.11 & - & 14.65 & - & - \\
\hline & & Core & 98.38 & 1.11 & 0.51 & - & - & - \\
\hline & \multirow{3}{*}{ Notched } & $\begin{array}{l}\text { Porous outer } \\
\text { layer }\end{array}$ & 61.27 & 0.81 & - & 18.65 & 19.27 & - \\
\hline & & $\begin{array}{l}\text { Compact } \\
\text { layer }\end{array}$ & 79.39 & 0.78 & - & 19.83 & - & - \\
\hline & & Core & 98.10 & 1.17 & 0.74 & - & - & - \\
\hline
\end{tabular}

* plain specimen (Figure 1b) and notched specimen (Figure 1c). 


\subsection{Microhardness}

The microhardness profiles obtained from the cross-section of plain as well as notched specimens made of $39 \mathrm{NiCrMo} 3$ in the untreated and treated conditions are shown in Figure 9. The effective depth of the QPQ treatment has been defined as the thickness of the region close to the specimen free surface which has a microhardness $100 \mathrm{HV}$ greater than that of the core. Figure 9a shows that in plain specimens the effective depth of the QPQ treatment is about $150 \mu \mathrm{m}$, the hardness being maximum and equal to about $730 \mathrm{HV}$ at the outer layer, while it equals $350 \mathrm{HV}$ at the core. On the other hand, Figure $9 \mathrm{~b}$ shows that in notched specimens, the effective depth is more reduced and equal to about $100 \mu \mathrm{m}$; the hardness is maximum and equal to about $600 \mathrm{HV}$ at the outer layer, while it equals $320 \mathrm{HV}$ at the core. It is worth noting that the hardness at the core of treated specimens remains almost the same as the hardness of the untreated specimens.
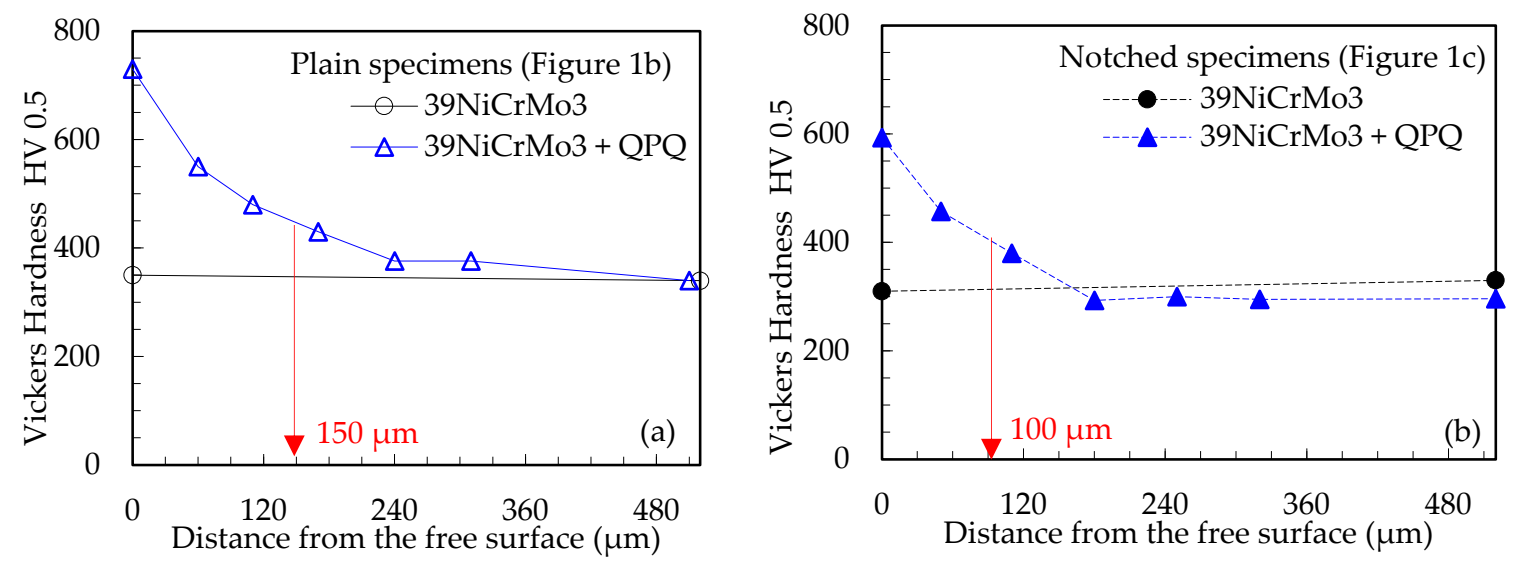

Figure 9. HV 0.5 measurements on cross-section of (a) plain specimens (Figure 1b) and (b) notched specimens (Figure 1c) made of 39NiCrMo3 and 39NiCrMo3 + QPQ steels.

\subsection{Surface Residual Stresses}

The axial $\sigma_{\mathrm{xx}}$ and hoop $\sigma_{\mathrm{zz}}$ surface residual stresses measured on the untreated and treated specimens have been reported in Table 3. It can be observed that the untreated specimens, both plain and notched, have compressive residual stresses in axial as well as hoop directions, their values being (-267) and (-130) MPa for plain specimens and (-48) and (-27) MPa for notched specimens. Therefore, residual stresses are about an order of magnitude higher in the case of plain specimens as compared to notched specimens. After the QPQ treatment, surface residual stresses became even more compressive, since they result about (-400) MPa in axial as well as hoop directions for both plain and notched specimens.

Table 3. Summary of residual stress measurement by the X-ray diffraction method (see Figure 3).

\begin{tabular}{cccc}
\hline \multirow{2}{*}{ Material } & Specimen Geometry & $\begin{array}{c}\boldsymbol{\sigma}_{\mathbf{x x}} \\
\mathbf{( M P a}\end{array}$ & $\begin{array}{c}\boldsymbol{\sigma}_{\mathbf{z z}} \\
\mathbf{( M P a})\end{array}$ \\
\hline \multirow{2}{*}{ 39NiCrMo3 } & plain & -267 & -130 \\
\multirow{2}{*}{$39 \mathrm{NiCrMo3}+\mathrm{QPQ}$} & notched & -48 & -27 \\
& plain & -418 & -408 \\
& notched & -412 & -364 \\
\hline
\end{tabular}

${ }^{*}$ plain specimen (Figure 1b) and notched specimen (Figure 1c). 


\subsection{Static Tests: Analysis of Fracture Surfaces and Stress-Strain Curves}

Figure 10 reports some examples of fracture surfaces generated by static testing plain specimens (Figure 1a). It can be observed that the untreated $39 \mathrm{NiCrMo} 3$ steel and the $\mathrm{X} 5 \mathrm{CrNiCuNb} 16-4$ stainless steel exhibited cup-cone fracture surfaces, which are typical of ductile materials, the cone-side being reported in Figure 10a,c, respectively. On the other hand, the $39 \mathrm{NiCrMo} 3$ steel after QPQ treatment exhibited an almost flat fracture surface, see Figure 10b, which is typical of brittle materials.

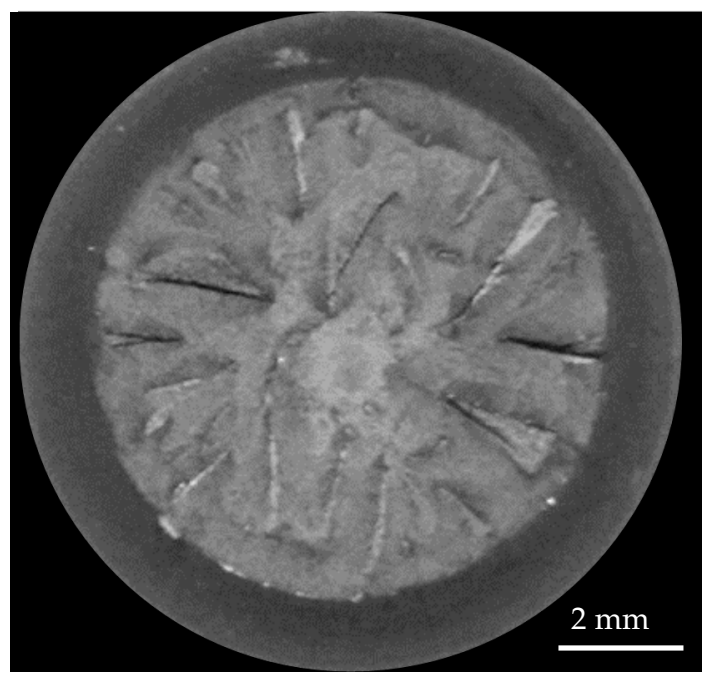

(a) Material: $39 \mathrm{NiCrMo} 3$

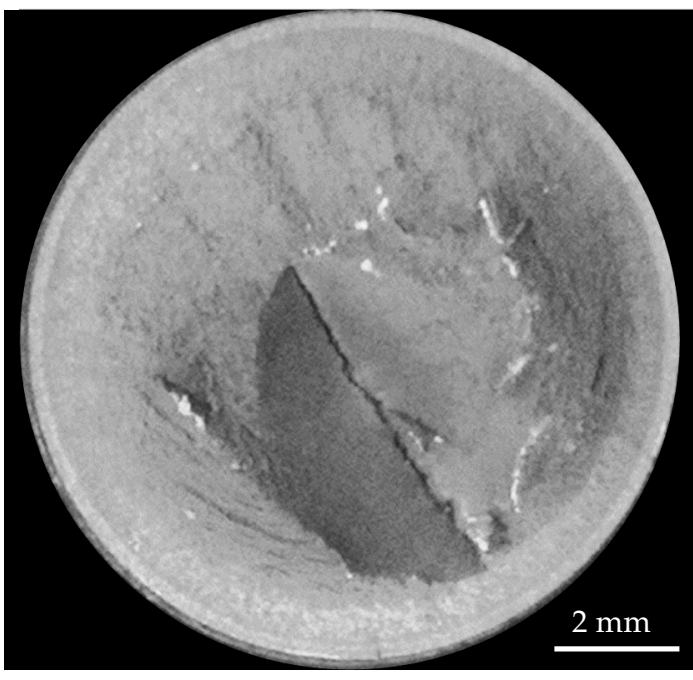

(b) Material: 39NiCrMo3 + QPQ

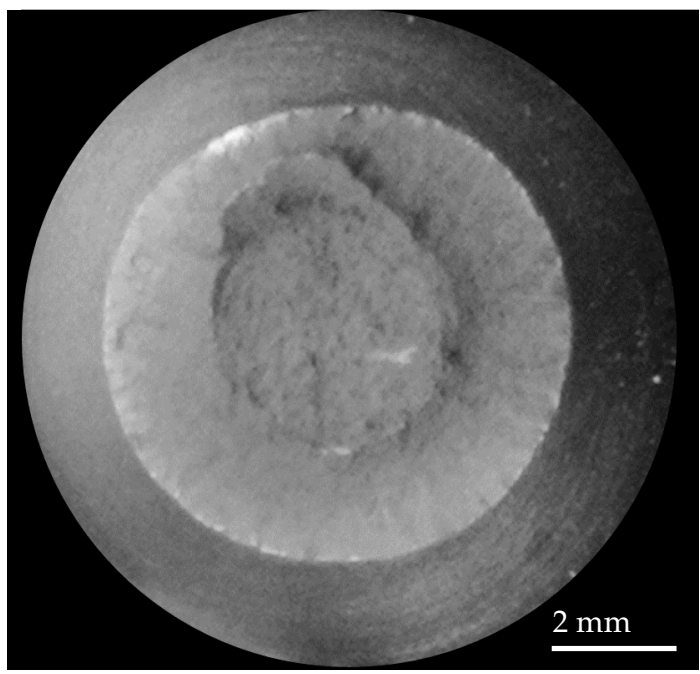

(c) Material: $\mathrm{X} 5 \mathrm{CrNiCuNb} 16-4$

Figure 10. Fracture surfaces of plain specimens (Figure 1a) after tensile static tests.

Tensile engineering stress-strain curves obtained from the static tests of three samples for each material, namely untreated and treated $39 \mathrm{NiCrMo} 3$ steel and $\mathrm{X} 5 \mathrm{CrNiCuNb} 16-4$ stainless steel, have been reported in Figure 11a-c, respectively, while Figure 11d reports a comparison between the stress-strain curves of the considered materials. The average mechanical properties obtained from the tensile tests are reported in Table 4. As a result, the Young's modulus E equals about 206,000 MPa and $190,000 \mathrm{MPa}$ for construction steel and stainless steel, respectively; the proof stress $\sigma_{\mathrm{p}, 02}$ is about equal to $1000 \mathrm{MPa}$ for all considered steels, the ultimate tensile strength $\sigma_{\mathrm{R}}$ is in the range 1117-1168 for the construction steel and equal to $1030 \mathrm{MPa}$ for the stainless steel, while the elongation after fracture $\mathrm{A} \%$ is in the range between $11 \%$ and $14 \%$, therefore all values are in good agreement with the nominal 
values for all tested materials. Moreover, Figure 11a,b and Table 4 show that the QPQ treatment does not affect the Young's modulus, the proof stress and the ultimate tensile strength, while it reduces the elongation after fracture from $14 \%$, for the untreated steel, to $11 \%$, for the treated steel, as previously observed from the comparison of the fracture surfaces of Figure 10a,b.
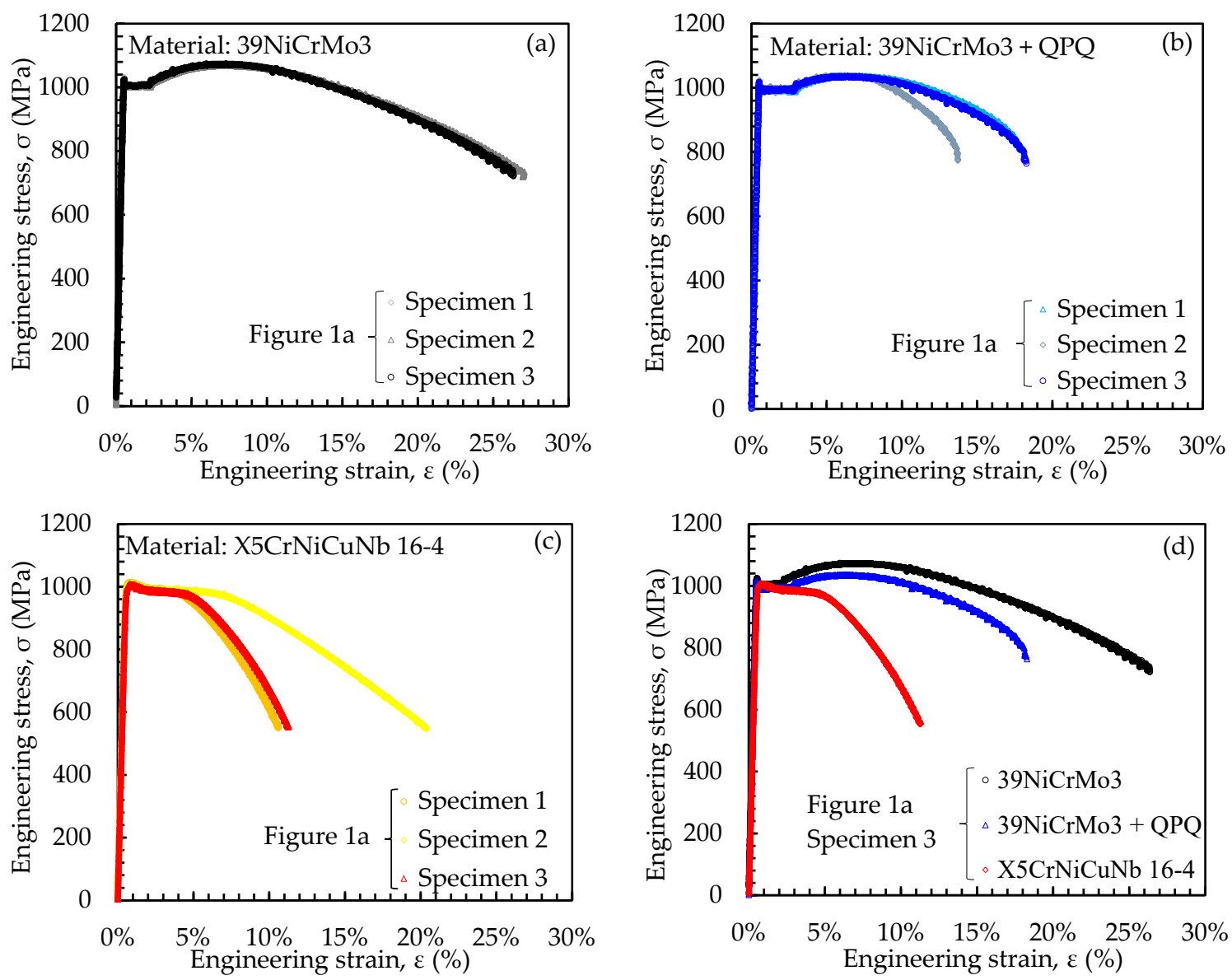

Figure 11. Static engineering stress-strain curves for (a) $39 \mathrm{NiCrMo} 3$, (b) $39 \mathrm{NiCrMo} 3+\mathrm{QPQ}$, (c) $\mathrm{X} 5 \mathrm{CrNiCuNb} 16-4$ steels. (d) Comparison between static curves of the considered steels.

Table 4. Summary of static test results.

\begin{tabular}{cccccccc}
\hline Material & $\begin{array}{c}\text { Specimen } \\
\text { Geometry }\end{array}$ & $\begin{array}{c}\mathbf{d}_{\text {net }} \\
(\mathbf{m m})\end{array}$ & $\begin{array}{c}\mathbf{d}_{\text {gross }} \\
(\mathbf{m m})\end{array}$ & $\begin{array}{c}\mathbf{E} \\
\mathbf{( M P a})\end{array}$ & $\begin{array}{c}\boldsymbol{\sigma}_{\mathbf{R}} \\
(\mathbf{M P a})\end{array}$ & $\begin{array}{c}\boldsymbol{\sigma}_{\mathbf{p}, \mathbf{0 2}} \\
\mathbf{( M P a})\end{array}$ & $\begin{array}{c}\mathbf{A} \\
\mathbf{( \% )}\end{array}$ \\
\hline 39NiCrMo3 & plain & 10 & 20 & 206,185 & 1168 & 1013 & 14.3 \\
39NiCrMo3 + QPQ & plain & 10 & 20 & 208,433 & 1117 & 1005 & 11.4 \\
X5CrNiCuNb 16-4 & plain & 10 & 20 & 191,871 & 1030 & 1020 & 12.4 \\
\hline
\end{tabular}

${ }^{*}$ plain specimen (Figure 1a).

\subsection{Fatigue Tests: Analysis of Fracture Surfaces and Woehler Curves}

Figures 12 and 13 report typical fracture surfaces of plain (Figure 1b) as well as notched (Figure 1c) specimens, respectively, subjected to axial fatigue loading. 


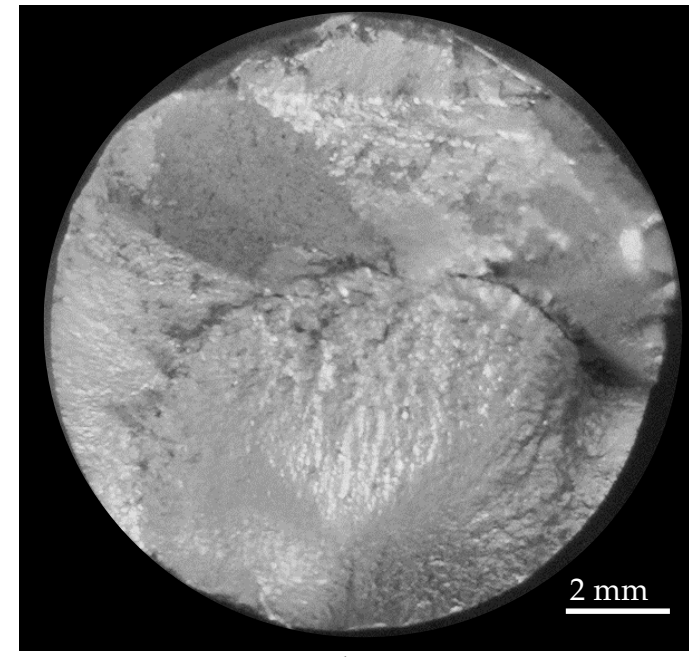

(a) Material: $39 \mathrm{NiCrMo} 3$

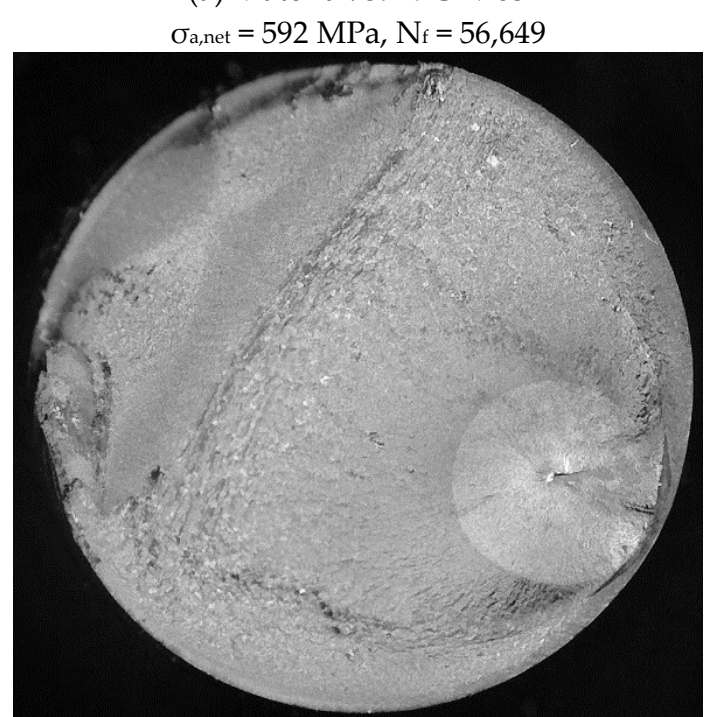

(c) Material: $39 \mathrm{NiCrMo} 3+\mathrm{QPQ}$ $\sigma_{\mathrm{a}, \text { net }}=468 \mathrm{MPa}, \mathrm{N}_{\mathrm{f}}=328,967$

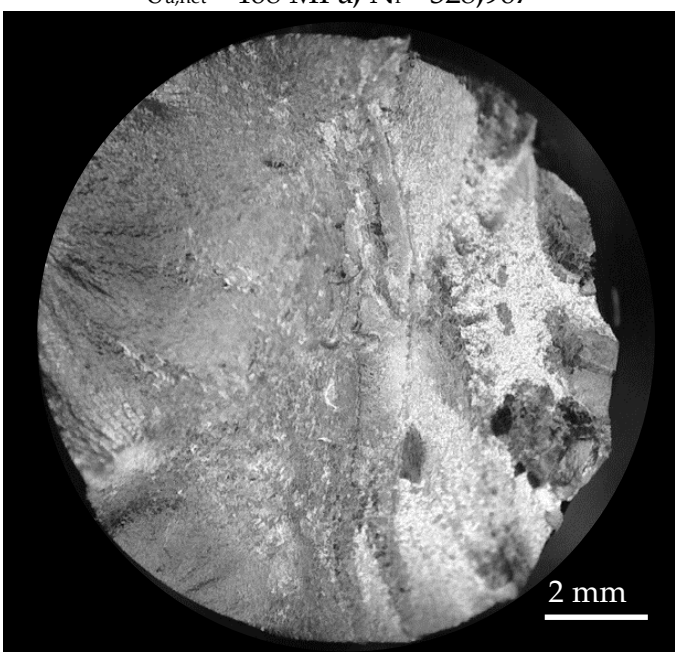

(e) Material: $\mathrm{X} 5 \mathrm{CrNiCuNb} 16-4$ $\sigma_{a, \text { net }}=619 \mathrm{MPa}, \mathrm{N}_{\mathrm{f}}=87,657$

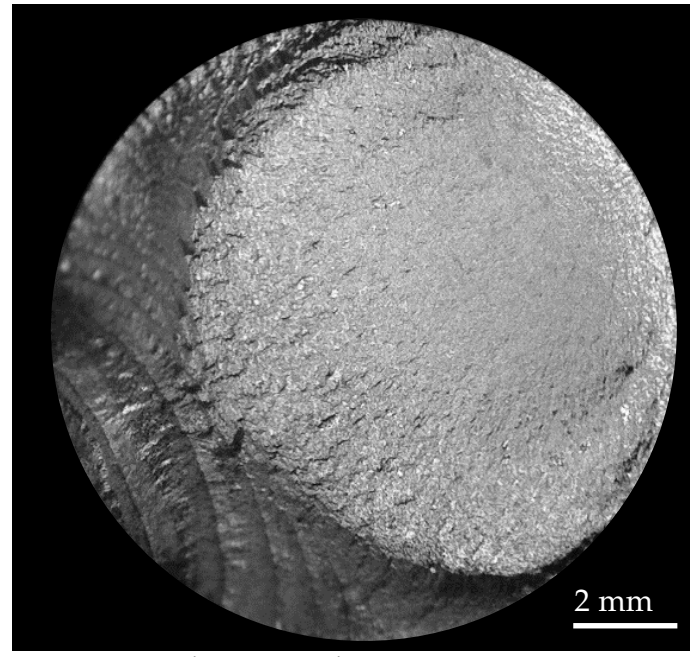

(b) Material: $39 \mathrm{NiCrMo} 3$

$\sigma_{\mathrm{a}, \text { net }}=350 \mathrm{MPa}, \mathrm{N}_{\mathrm{f}}=694,334$

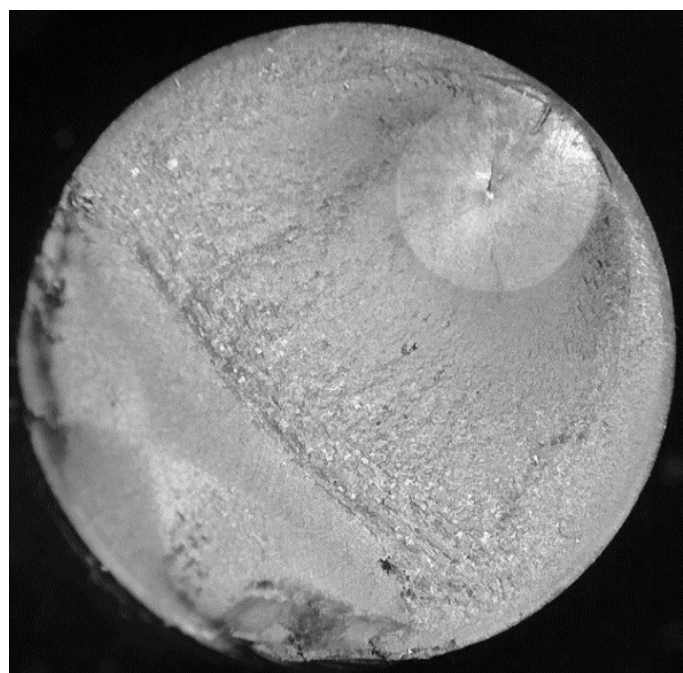

(d) Material: $39 \mathrm{NiCrMo} 3+\mathrm{QPQ}$

$\sigma_{\mathrm{a}, \mathrm{net}}=416 \mathrm{MPa}, \mathrm{N}_{\mathrm{f}}=3,204,813$

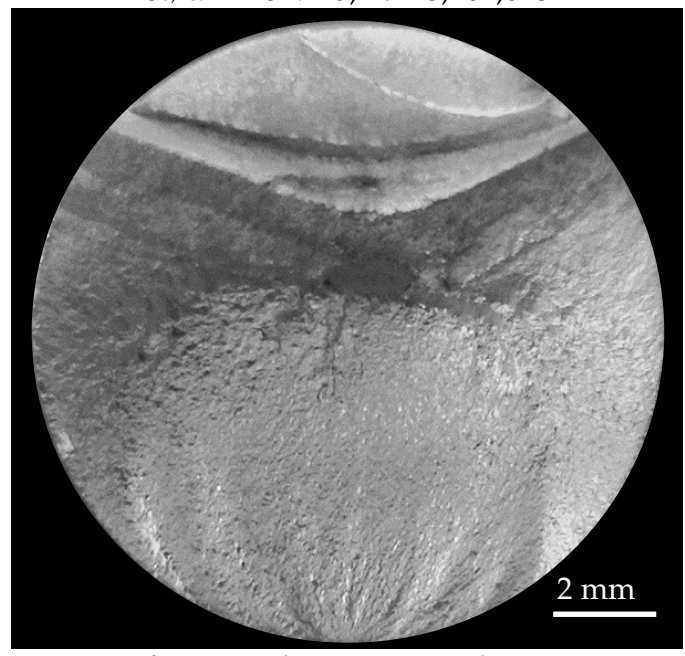

(f) Material: X5CrNiCuNb 16-4 $\sigma_{a, \text { net }}=504 \mathrm{MPa}, \mathrm{N}_{\mathrm{f}}=363,971$

Figure 12. Fracture surfaces after axial fatigue tests of plain specimens (Figure $1 \mathbf{b}$ ) made of $(\mathbf{a}, \mathbf{b})$ 39NiCrMo3, (c, d) 39NiCrMo3 + QPQ, (e,f) X5CrNiCuNb 16-4 steels. 


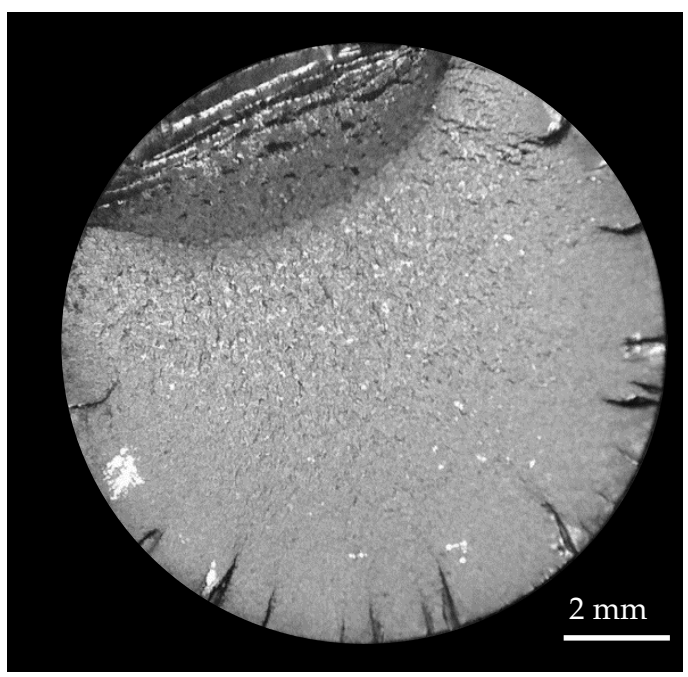

(a) Material: $39 \mathrm{NiCrMo} 3$ $\sigma_{\mathrm{a}, \text { net }}=311 \mathrm{MPa}, \mathrm{N}_{\mathrm{f}}=63,739$

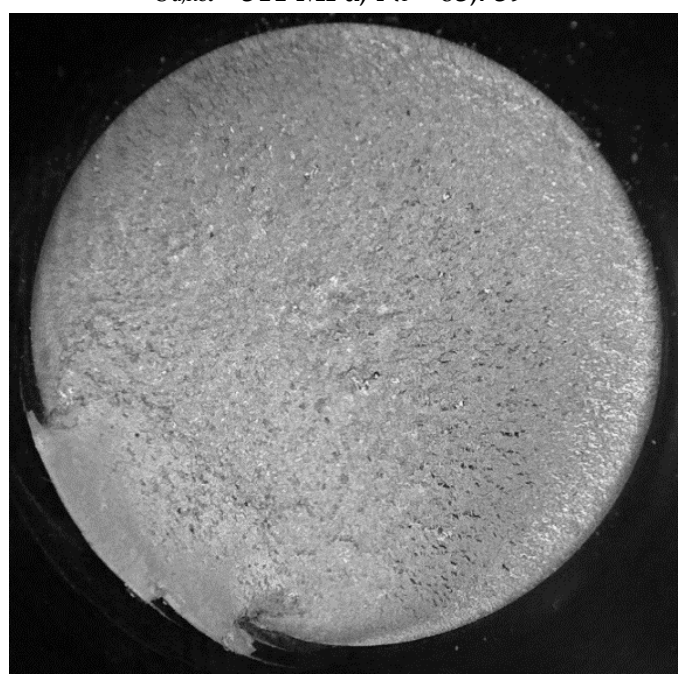

(c) Material: $39 \mathrm{NiCrMo} 3+\mathrm{QPQ}$ $\sigma_{\mathrm{a}, \text { net }}=453 \mathrm{MPa}, \mathrm{N}_{\mathrm{f}}=52,293$

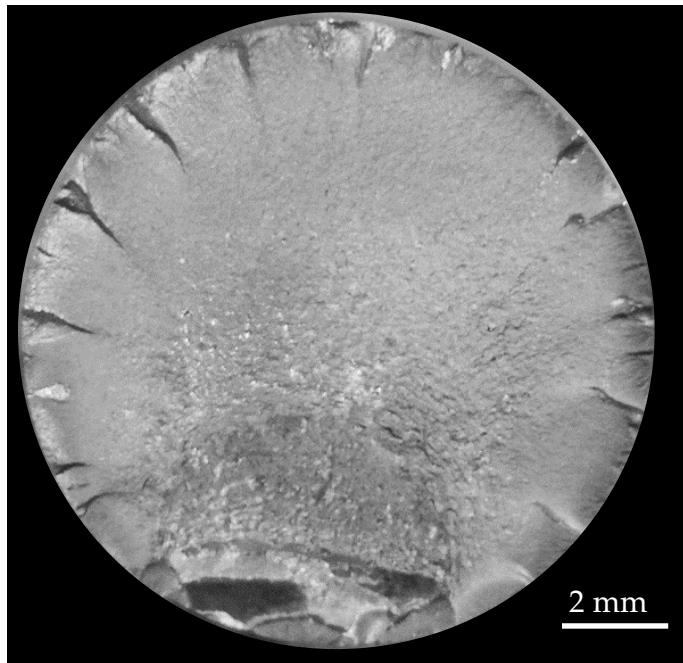

(e) Material: $\mathrm{X} 5 \mathrm{CrNiCuNb} 16-4$ $\sigma_{\mathrm{a}, \text { net }}=368 \mathrm{MPa}, \mathrm{N}_{\mathrm{f}}=75,085$

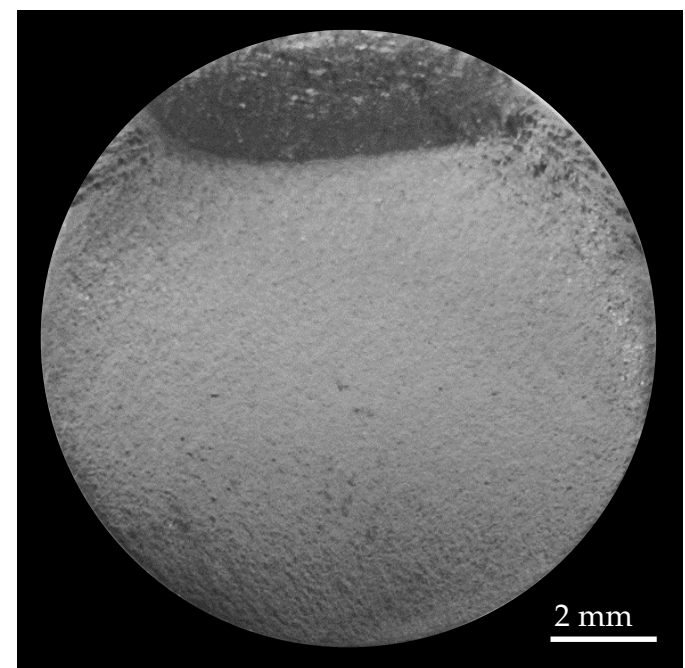

(b) Material: $39 \mathrm{NiCrMo} 3$ $\sigma_{\mathrm{a}, \text { net }}=209 \mathrm{MPa}, \mathrm{N}_{\mathrm{f}}=725,270$

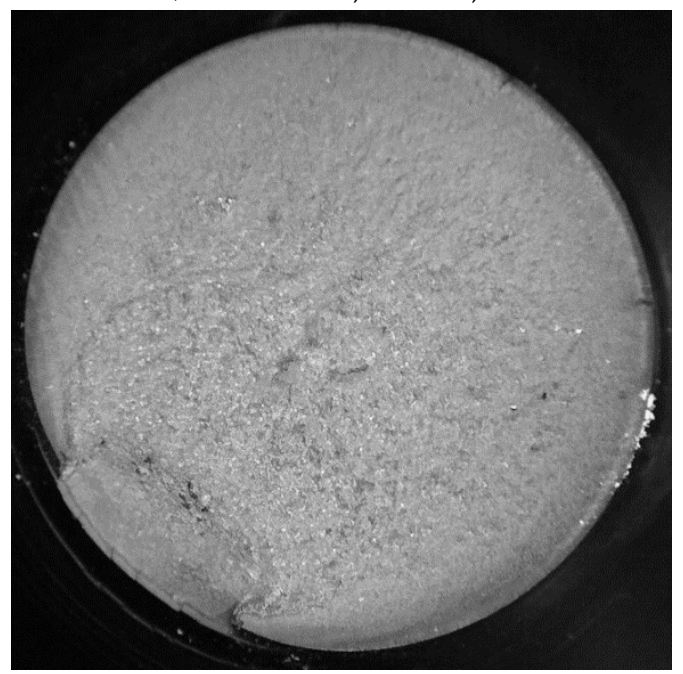

(d) Material: 39NiCrMo3 + QPQ $\sigma_{\mathrm{a}, \text { net }}=368 \mathrm{MPa}, \mathrm{N}_{\mathrm{f}}=837,185$

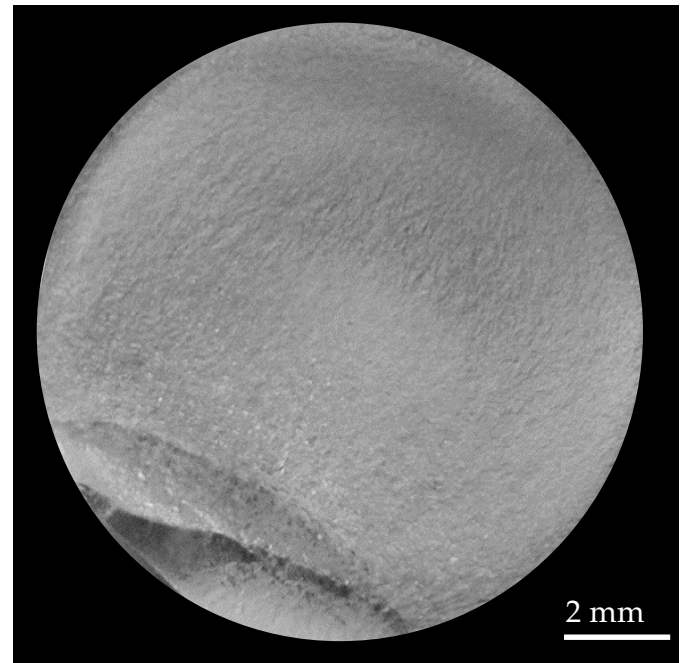

(f) Material: $\mathrm{X} 5 \mathrm{CrNiCuNb} 16-4$ $\sigma_{a, \text { net }}=266 \mathrm{MPa}, \mathrm{N}_{\mathrm{f}}=893,692$

Figure 13. Fracture surfaces after axial fatigue tests of notched specimens (Figure 1c) made of (a,b) 39NiCrMo3, (c,d) 39NiCrMo3 + QPQ, (e,f) X5CrNiCuNb 16-4 steels. 
Concerning plain specimens, Figure 12 shows that the untreated $39 \mathrm{NiCrMo} 3$ steel and the $\mathrm{X} 5 \mathrm{CrNiCuNb} 16-4$ stainless steel exhibited crack initiation from the surface of the specimens. On the other hand, the QPQ treatment applied to $39 \mathrm{NiCrMo} 3$ steel shifted the crack initiation location from the outer surface into the specimen core at internal defects. This is due to the increase of surface microhardness and the presence of high compressive surface residual stresses, which inhibited crack initiation from the surface of the specimens; this phenomenon is reported in the literature dealing with different steels subjected to QPQ treatment [35,37].

Dealing with notched specimens, it can be observed that in all tested materials the crack initiated from the notch tip, driven by the dominant notch stress concentration effect. Under high load levels, multiple crack initiation locations have been observed at different angular positions along the notch tip, see Figure 13a,e.

The experimental fatigue results relevant to each material, namely untreated and treated $39 \mathrm{NiCrMo} 3$ steel and $\mathrm{X} 5 \mathrm{CrNiCuNb} 16-4$ stainless steel, and expressed in terms of number of cycles to failure $\mathrm{N}_{\mathrm{f}}$ as a function of the applied nominal net-section stress amplitude $\sigma_{\mathrm{a} \text {,net }}$ (Equation (1)) have been reported in Figure 14a,c, respectively. Figure 14d reports a comparison between the $50 \%$-survival-probability fatigue curves of the considered steels. The scatter bands included in Figure $14 \mathrm{a}-\mathrm{c}$ are referred to survival probabilities of 10 and $90 \%$ and to a $95 \%$ confidence level. The main fatigue test results, i.e., the high-cycle fatigue strengths referred to a survival probability of $50 \%$ and 5 million loading cycles and the inverse slope $k$, have been summarised in Table 5 .

Figure 14a shows that the untreated $39 \mathrm{NiCrMo} 3$ steel has high-cycle fatigue strengths of $241 \mathrm{MPa}$ and $133 \mathrm{MPa}$ for the plain and notched configuration, respectively, while the inverse slope $k$ and the scatter index $T_{\sigma}$ equal about 5 and 1.2, respectively, for both specimen geometries.

Dealing with the treated $39 \mathrm{NiCrMo} 3$ steel, Figure $14 \mathrm{~b}$ reports that high-cycle fatigue strengths are equal to $396 \mathrm{MPa}$ and $319 \mathrm{MPa}$, the inverse slopes $k$ are equal to 10 and 13 and scatter indexes $\mathrm{T}_{\sigma}$ are equal to 1.54 and 1.25 , for plain and notched specimens, respectively.

Concerning the $\mathrm{X} 5 \mathrm{CrNiCuNb} 16-4$ stainless steel, Figure $14 \mathrm{c}$ shows that the high-cycle fatigue strengths are equal to $328 \mathrm{MPa}$ and $205 \mathrm{MPa}$, the inverse slopes $\mathrm{k}$ result 6.40 and 7.54, while the scatter indexes $T_{\sigma}$ are equal to 1.22 and 1.23 , for plain and notched specimens, respectively.

Finally, Figure 14d highlights that the QPQ treatment applied to 39NiCrMo3 steel has improved the fatigue strength of both plain and notched specimens as compared to the untreated material. This is due to the following phenomena:

(1) The increase of surface microhardness, as it has extensively been discussed by Murakami [40] who derived also an empirical linear dependence between the hardness and the fatigue limit of steels and showed that the higher the hardness, the higher the fatigue strength;

(2) The generation of high compressive surface residual stresses, which tend to close the fatigue crack and then to retard crack propagation [41,42], this increases the total fatigue life especially at low load levels, while at high load levels the beneficial effect of compressive residual stresses is less pronounced.

More in detail, the QPQ treatment leads to $65 \%$ and $140 \%$ increase of the high-cycle fatigue strengths as compared to the untreated material when dealing with plain and notched specimens, respectively. Furthermore, the high-cycle fatigue strength of $39 \mathrm{NiCrMo} 3$ steel after QPQ treatment results even higher than that relevant to the stainless steel. 

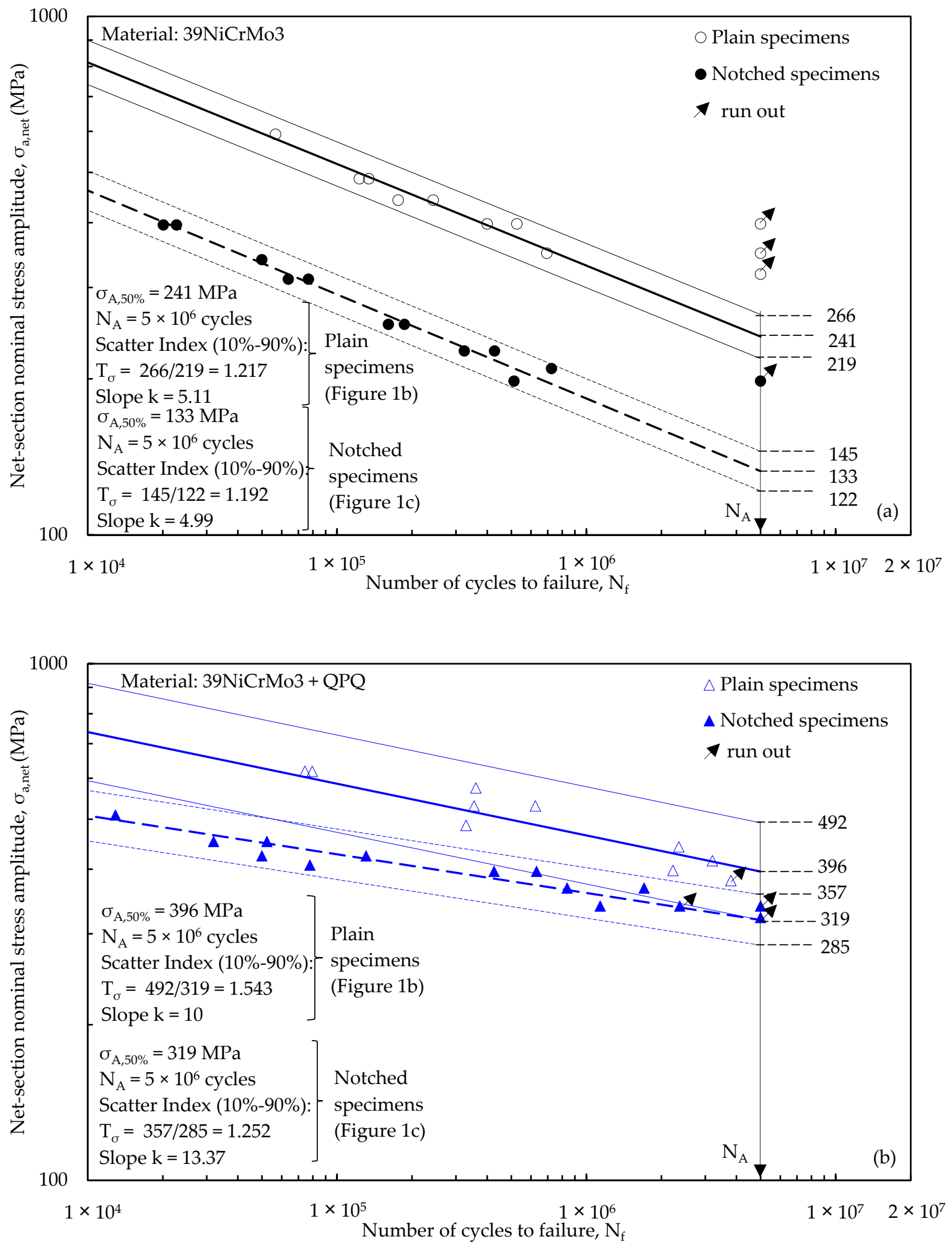

Figure 14. Cont. 

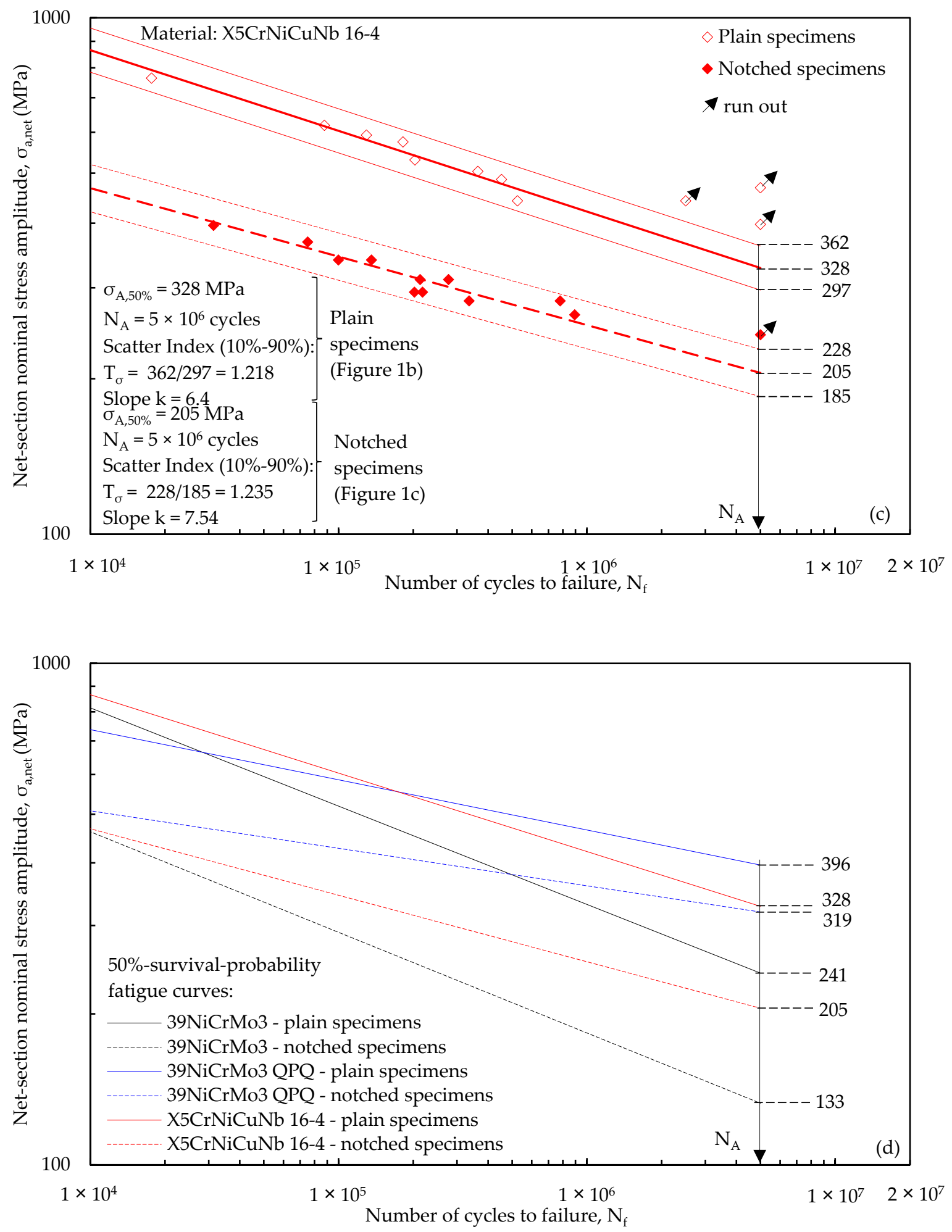

Figure 14. Experimental fatigue results generated by plain (Figure 1b) and notched (Figure 1c) specimens tested under axial loading and expressed in terms of number of cycles to failure as a function of applied nominal net-section stress amplitude for (a) 39NiCrMo3, (b) 39NiCrMo3 + QPQ, (c) $\mathrm{X} 5 \mathrm{CrNiCuNb} 16-4$ steels. (d) Comparison between the 50\%-survival-probability fatigue curves of the considered steels. 
Table 5. Summary of fatigue test results.

\begin{tabular}{|c|c|c|c|c|c|c|c|c|c|c|}
\hline Material & $\begin{array}{l}\text { Specimen } \\
\text { Geometry * }\end{array}$ & $\begin{array}{c}\rho \\
(\mathrm{mm})\end{array}$ & $\begin{array}{l}d_{\text {net }} \\
(\mathrm{mm})\end{array}$ & $\begin{array}{l}d_{\text {gross }} \\
(\mathrm{mm})\end{array}$ & $\begin{array}{l}\mathrm{Ra}^{\hat{1}} \\
(\mu \mathrm{m})\end{array}$ & $K_{t, \text { net }}$ & $\begin{array}{c}\mathrm{N}^{\circ} \\
\text { Data }\end{array}$ & $\begin{array}{c}\mathbf{N}^{\circ} \\
\text { Runout }\end{array}$ & $\begin{array}{c}\sigma_{\mathrm{A}}^{+} \\
(\mathrm{MPa})\end{array}$ & $\mathbf{k}^{\circ}$ \\
\hline \multirow{2}{*}{ 39NiCrMo3 } & plain & - & \multirow{2}{*}{12} & \multirow{2}{*}{20} & \multirow{2}{*}{0.83} & 1.05 & 12 & 3 & 241 & 5.11 \\
\hline & notched & 1.5 & & & & 2.34 & 12 & 1 & 133 & 4.99 \\
\hline \multirow{2}{*}{$\begin{array}{l}\text { 39NiCrMo3 } \\
+ \text { QPQ }\end{array}$} & plain & - & \multirow{2}{*}{12} & \multirow{2}{*}{20} & \multirow{2}{*}{0.84} & 1.05 & 11 & 1 & 396 & 10.0 \\
\hline & notched & 1.5 & & & & 2.34 & 14 & 3 & 319 & 13.37 \\
\hline X5CrNiCuNb & plain & - & \multirow{2}{*}{12} & \multirow{2}{*}{20} & \multirow{2}{*}{0.76} & 1.05 & 11 & 3 & 328 & 6.40 \\
\hline $16-4$ & notched & 1.5 & & & & 2.34 & 12 & 1 & 205 & 7.54 \\
\hline
\end{tabular}

*-plain specimen (Figure 1b) and notched specimen (Figure 1c). ^-the roughness parameter Ra was measured along a path parallel to the specimen axis. Measurements were performed by using a surface roughness tester (Taylor Hobson precision-Surtronic 25) having a measurement uncertainty of $5 \%$. +- high-cycle fatigue strength referred to a nominal load ratio $\mathrm{R}=\sigma_{\min } / \sigma_{\max }=-1$, a total fatigue life $\mathrm{N}_{\mathrm{A}}=5 \times 10^{6}$ cycles and a survival probability $50 \%{ }^{\circ}-\mathrm{k}$ is the inverse slope of the relevant Woehler curve.

\section{Conclusions}

In the present paper, the effects of the salt bath nitrocarburizing and post-oxidation heat treatment, known also as QPQ, on the static and fatigue behaviours of $39 \mathrm{NiCrMo3}$ construction steel have been investigated. To do this, the microstructure of the untreated and treated $39 \mathrm{NiCrMo} 3$ steel have been identified by metallographic and SEM analysis; moreover, the micro-hardness and surface residual stress profiles have been measured. Afterwards, plain as well as notched specimens made of $39 \mathrm{NiCrMo} 3$ construction steel, both untreated and treated have been tested under static and fatigue loadings and the fracture surfaces have been analysed. For comparison purposes, $\mathrm{X} 5 \mathrm{CrNiCuNb}$ 16-4 stainless steel specimens have been tested and analysed as well. The following conclusions can be drawn:

(1) The QPQ treatment applied to specimens made of $39 \mathrm{NiCrMo3}$ steel generated a surface porous layer having high microhardness and high compressive residual stresses. The hardening mechanism in the treated samples was due to the diffusion of nitrogen and carbon into the steel. During the process, a layer was formed consisting of the outer compound layer ( $\varepsilon$-iron nitride) and the diffusion layer thereunder. The outer layer consisted of compounds of iron, nitrogen, carbon and oxygen and did not possess metallic properties. In the diffusion layer, nitrogen and carbon content was higher than in the substrate. Part of these elements remained in solid solution and part of them precipitated into the substrate as carbonitride needles. The increased amount of elements in solid solution and the precipitate contributed to the increase of both hardness and compressive residual stresses in the diffusion layer, which affected both static and fatigue behaviours of the treated material.

(2) Dealing with the static behaviour, the QPQ treatment made the material slightly more brittle: the fracture surfaces changed from the typical cup-cone configuration to a flat surface; moreover, the elongation after fracture reduced from $14 \%$, for the untreated steel, to $11 \%$, for the treated steel.

(3) Concerning the fatigue behaviour, the QPQ treatment shifted the crack initiation location of plain specimens from the surface, for the untreated steel, to the core, for the treated material; while cracks always initiated at the notch tip in notched specimens, regardless the material condition. Furthermore, the QPQ treatment has to an increase of $65 \%$ and $140 \%$ of the high-cycle fatigue strength as compared to the untreated material, for plain and notched specimens, respectively. This behaviour is due to the increase of surface microhardness and the generation of high compressive surface residual stresses, which tend to close the fatigue crack and then to retard crack propagation: as a result, the total fatigue life is extended especially at low load levels.

(4) The fatigue strength of the treated steel resulted higher than that of the stainless steel.

(5) Finally, it has been confirmed that the salt bath nitrocarburizing and post-oxidation heat treatment, enables an improvement in the fatigue behaviour of $39 \mathrm{NiCrMo} 3$ construction steel, both in the plain and in the notched configuration, while the static performances remain almost unchanged. 
Author Contributions: The paper was conceptualized by all the authors. The microstructure analysis and microhardness and residual stress measurements were performed by M.D. The static and fatigue experimental tests were carried out by A.C. The experimental data were reanalyzed by G.M., A.C. All the authors contributed to the original version of the paper.

Funding: This research received no external funding.

Conflicts of Interest: The authors declare no conflict of interest.

\section{References}

1. Almeida, E. Surface Treatments and Coatings for Metals. A General Overview. 1. Surface Treatments, Surface Preparation, and the Nature of Coatings. Ind. Eng. Chem. Res. 2001, 40, 3-14. [CrossRef]

2. Sørensen, P.A.; Kiil, S.; Dam-Johansen, K.; Weinell, C.E. Anticorrosive coatings: A review. J. Coat. Technol. Res. 2009, 6, 135-176. [CrossRef]

3. Schulze, V. Modern Mechanical Surface Treatment: States, Stability, Effects; Wiley-VCH: Hoboken, NJ, USA, 2006; ISBN 9783527313716.

4. Vetter, J. Surface Treatments for Automotive Applications. In Coating Technology for Vehicle Applications; Springer International Publishing: Cham, Switzerland, 2015; pp. 91-132.

5. Bell, T. Ferritic nitrocarburising. Heat Treat. Met. 1975, 2, 39-49.

6. Bell, T. Gaseous and plasma nitrocarburizing. In ASM Handbook; ASM International: Materials Park, $\mathrm{OH}$, USA, 1991; Volume 4, pp. 425-436.

7. Mehrkam, Q.; Easterday, J.; Payne, B.; Foreman, R.; Vukovich, D.; Godding, A. Liquid nitriding of steels. In ASM Handbook; ASM International: Materials Park, OH, USA, 1991; Volume 4, pp. 410-419.

8. Krishnaraj, N.; Iyer, K.J.L.; Sundaresan, S. Scuffing resistance of salt bath nitrocarburized medium carbon steel. Wear 1997, 210, 237-244. [CrossRef]

9. Alsaran, A.; Karakan, M.; Celik, A.; Bulbul, F.; Efeoglu, I. Study on compound layer formed during plasma nitrocarburizing of AISI 5140 steel. J. Mater. Sci. Lett. 2003, 22, 1759-1761. [CrossRef]

10. Limodin, N.; Verreman, Y. Fatigue strength improvement of a 4140 steel by gas nitriding: Influence of notch severity. Mater. Sci. Eng. 2006, 435-436, 460-467. [CrossRef]

11. Funatani, K. Low-Temperature Salt Bath Nitriding of Steels. Met. Sci. Heat Treat. 2004, 46, 277-281. [CrossRef]

12. Kunst, H. Improving Corrosion and Wear Resistance by Salt Bath Nitrocarburizing Plus Oxidizing in Automated Facilities; Pergamon Press: Oxford, UK, 1987.

13. Wahl, G. Component properties after salt bath nitrocarburizing by Tufftride process. Heat Treat. Met. 1995, 3, 65-73.

14. Li, H.; Luo, D.; Yeung, C.; Lau, K. Microstructural studies of QPQ complex salt bath heat-treated steels. J. Mater. Process. Technol. 1997, 69, 45-49. [CrossRef]

15. Qiang, Y.H.; Ge, S.R.; Xue, Q.J. Microstructure and tribological behaviour of nitrocarburizing-quenching duplex treated steel. Tribol. Int. 1999, 32, 131-136. [CrossRef]

16. Yeung, C.F.; Lau, K.H.; Li, H.Y.; Luo, D.F. Advanced QPC complex salt bath heat treatment. J. Mater. Process. Technol. 1997, 66, 249-252. [CrossRef]

17. Marušić, K.; Otmačić, H.; Landek, D.; Cajner, F.; Stupnišek-Lisac, E. Modification of carbon steel surface by the Tenifer ${ }^{\circledR}$ process of nitrocarburizing and post-oxidation. Surf. Coat. Technol. 2006, 201, 3415-3421. [CrossRef]

18. Li, G.; Wang, J.; Peng, Q.; Li, C.; Wang, Y.; Shen, B. Influence of salt bath nitrocarburizing and post-oxidation process on surface microstructure evolution of 17-4PH stainless steel. J. Mater. Process. Technol. 2008, 207, 187-192. [CrossRef]

19. Shiozawa, K.; Lu, L.; Ishihara, S. S-N curve characteristics and subsurface crack initiation behaviour in ultra-long life fatigue of a high carbon-chromium bearing steel. Fatigue Fract. Eng. Mater. Struct. 2001, 24, 781-790. [CrossRef]

20. Chandran, K.R.; Chang, P.; Cashman, G.T. Competing failure modes and complex S-N curves in fatigue of structural materials. Int. J. Fatigue 2010, 32, 482-491. [CrossRef]

21. Cashman, G.T. A review of Competing Modes fatigue behavior. Int. J. Fatigue 2010, 32, 492-496. [CrossRef]

22. Sakai, T.; Sato, Y.; Oguma, N. Characteristic S-N properties of high-carbon-chromium-bearing steel under axial loading in long-life fatigue. Fatigue Fract. Eng. Mater. Struct. 2002, 25, 765-773. [CrossRef] 
23. Bathias, C. There is no infinite fatigue life in metallic materials. Fatigue Fract. Eng. Mater. Struct. 1999, 22, 559-565. [CrossRef]

24. Limodin, N.; Verreman, Y.; Tarfa, T.N. Axial fatigue of a gas-nitrided quenched and tempered AISI 4140 steel: Effect of nitriding depth. Fatigue Fract. Eng. Mater. Struct. 2003, 26, 811-820. [CrossRef]

25. Wang, Q.Y.; Berard, J.Y.; Dubarre, A.; Baudry, G.; Rathery, S.; Bathias, C. Gigacycle fatigue of ferrous alloys. Fatigue Fract. Eng. Mater. Struct. 1999, 22, 667-672. [CrossRef]

26. Preston, S. Bending fatigue strength of nitrocarburized steel SS2244. Mater. Sci. Eng. 1993, 160, 7-15. [CrossRef]

27. Genel, K.; Demirkol, M.; Çapa, M. Effect of ion nitriding on fatigue behaviour of AISI 4140 steel. Mater. Sci. Eng. 2000, 279, 207-216. [CrossRef]

28. Suh, C.-M.; Hwang, J.-K.; Son, K.-S.; Jang, H.-K. Fatigue characteristics of nitrided SACM 645 according to the nitriding condition and notch. Mater. Sci. Eng. 2005, 392, 31-37. [CrossRef]

29. Tokaji, K.; Takahashi, S. Fatigue Strength and Subsurface Crack Initiation in Nitrided Low Alloy Steel SCM 435. Trans. Jpn. Soc. Mech. Eng. 2001, 67, 86-93. [CrossRef]

30. Hussain, K.; Tauqir, A.; ul Haq, A.; Khan, A. Influence of gas nitriding on fatigue resistance of maraging steel. Int. J. Fatigue 1999, 21, 163-168. [CrossRef]

31. Spies, H.J.; Trubitz, P. Fatigue of nitrided steels. In Fatigue 96; Elsevier: Berlin, Germany, 1996; pp. $1409-1414$.

32. Li, G.; Peng, Q.; Wang, J.; Li, C.; Wang, Y.; Gao, J.; Chen, S.; Shen, B. Surface microstructure of 316L austenitic stainless steel by the salt bath nitrocarburizing and post-oxidation process known as QPQ. Surf. Coat. Technol. 2008, 202, 2865-2870. [CrossRef]

33. Yamada, Y.; Eto, H.; Konya, J.; Takahashi, K. Influence of crack-like surface defects on the fatigue limit of nitrocarburized carbon steel. IOP Conf. Ser. Mater. Sci. Eng. 2018, 372, 012005. [CrossRef]

34. Zhang, J.W.; Lu, L.T.; Shiozawa, K.; Zhou, W.N.; Zhang, W.H. Effects of nitrocarburizing on fatigue property of medium carbon steel in very high cycle regime. Mater. Sci. Eng. 2011, 528, 7060-7067. [CrossRef]

35. Zhang, J.W.; Lu, L.T.; Shiozawa, K.; Cui, G.D.; Zhang, W.H. Fatigue properties of oxynitrocarburized medium carbon railway axle steel in very high cycle regime. Int. J. Fatigue 2010, 32, 1805-1811. [CrossRef]

36. Zhao, H.; Torres, A.; Prisbell, A.; Werner, A.; Abdelaal, A. Quench Polish Quench (QPQ) Coating Behavior Under Dynamic Loads. In Proceedings of the ASME 2017 International Mechanical Engineering Congress and Exposition, Tampa, FL, USA, 3-9 November 2017; American Society of Mechanical Engineers: New York, NY, USA, 2017.

37. Zhang, J.W.; Lu, L.T.; Shiozawa, K.; Zhou, W.N.; Zhang, W.H. Effect of nitrocarburizing and post-oxidation on fatigue behavior of 35CrMo alloy steel in very high cycle fatigue regime. Int. J. Fatigue 2011, 33, 880-886. [CrossRef]

38. Pérez, M.; Belzunce, F.J. A comparative study of salt-bath nitrocarburizing and gas nitriding followed by post-oxidation used as surface treatments of H13 hot forging dies. Surf. Coat. Technol. 2016, 305, 146-157. [CrossRef]

39. Nobuki, T.; Hatate, M.; Kawasaki, Y.; Ikuta, A.; Hamasaka, N. Effects of Nitriding and Nitro-carburizing on the Fatigue Properties of Ductile Cast Iron. Int. J. Met. 2017, 11, 52-60. [CrossRef]

40. Murakami, Y. Metal Fatigue: Effects of Small Defects and Nonmetallic Inclusions; Elsevier Science Ltd.: Amsterdam, The Netherlands, 2002; ISBN 9780128138762.

41. Throop, J.; Reemsnyder, H. (Eds.) Residual Stress Effects in Fatigue; ASTM International: West Conshohocken, PA, USA, 1982; ISBN 978-0-8031-0711-3.

42. Stephens, R.I.; Fatemi, A.; Stephens, R.R.; Fuchs, H.O. Metal Fatigue in Engineering; Wiley: Hoboken, NJ, USA, 2001; ISBN 9780471510598.

(C) 2019 by the authors. Licensee MDPI, Basel, Switzerland. This article is an open access article distributed under the terms and conditions of the Creative Commons Attribution (CC BY) license (http://creativecommons.org/licenses/by/4.0/). 